IZA DP No. 6811

Coping with Intra-Household Job Separation in South Africa's Labor Market

Zoë M. McLaren

August 2012 


\title{
Coping with Intra-Household Job Separation in South Africa's Labor Market
}

\author{
Zoë M. McLaren \\ University of Michigan \\ and IZA
}

Discussion Paper No. 6811

August 2012

\author{
IZA \\ P.O. Box 7240 \\ 53072 Bonn \\ Germany \\ Phone: $+49-228-3894-0$ \\ Fax: +49-228-3894-180 \\ E-mail: iza@iza.org
}

Any opinions expressed here are those of the author(s) and not those of IZA. Research published in this series may include views on policy, but the institute itself takes no institutional policy positions.

The Institute for the Study of Labor (IZA) in Bonn is a local and virtual international research center and a place of communication between science, politics and business. IZA is an independent nonprofit organization supported by Deutsche Post Foundation. The center is associated with the University of Bonn and offers a stimulating research environment through its international network, workshops and conferences, data service, project support, research visits and doctoral program. IZA engages in (i) original and internationally competitive research in all fields of labor economics, (ii) development of policy concepts, and (iii) dissemination of research results and concepts to the interested public.

IZA Discussion Papers often represent preliminary work and are circulated to encourage discussion. Citation of such a paper should account for its provisional character. A revised version may be available directly from the author. 


\section{ABSTRACT}

\section{Coping with Intra-Household Job Separation in South Africa's Labor Market ${ }^{*}$}

In the context of South Africa's pervasive poverty and mass unemployment, households provide an important private safety net for the unemployed. Using new South African Labour Force Survey panel data, I investigate how households cope with job separations and the resulting loss of earned income. Unsurprisingly, I find no evidence of an added worker effect among either men or women. Neither increases in employment or labor market attachment in the year following a household job separation. Instead, households rely on remittances and, to a lesser extent, savings in the wake of a job separation. I find some evidence that households are worse off after a job separation: households reduce expenditures (even in the absence of household composition changes), hold fewer financial assets and are more likely to report frequent food insecurity. Households have viable income replacement strategies to cope with the loss of earned income in the short run, but over the long run job separations are likely to strain these strategies. Addressing structural factors in the labor market that constrain an individual's response to a household shock will enable households to respond more quickly to adverse employment events and limit the long term negative repercussions.

JEL Classification: J22, O15

Keywords: employment, participation, added worker effect, pension, South Africa, developing countries

Corresponding author:

Zoë M. McLaren

School of Public Health

University of Michigan

1415 Washington Heights, M3166

Ann Arbor, Ml 48109

USA

E-mail: zmclaren@umich.edu

\footnotetext{
* I thank Raj Arunachalam, John DiNardo, David Lam, Jim Levinsohn, Matt Rutledge, Jeff Smith, seminar participants at the University of Cape Town and two anonymous referees for helpful comments and Seble Worku and Jacques deKlerk at Statistics South Africa for assistance with the data.
} 


\section{Introduction}

South Africa has one of the highest unemployment rates in the world. More than ten years after the end of the Apartheid regime, the unemployment rate is still above 25 percent under the International Labor Organization (ILO) classification. By excluding discouraged workers, this official unemployment rate severely underestimates the true burden of unemployment, which is above 40 percent under the broad classification. ${ }^{1}$ Black Africans and adults under 35 years old are disproportionately affected, and a large proportion of the unemployed have never held a job. This study examines individual and household responses to job separation in such a high unemployment environment. New Labour Force Survey (LFS) household panel data promises to offer insight into the unemployment problem by allowing researchers to track both individuals who transition between employment and unemployment and their households as they adjust to the loss of earned income. A better understanding of the factors that determine labor market transitions and the accompanying household-level changes will enable the government to design more effective policy interventions.

After the fall of the Apartheid regime in 1994, Black African, Coloured and Indian workers who had previously been restricted from entering the cities or from obtaining certain types of employment joined the workforce en

\footnotetext{
${ }^{1}$ South Africa Labour Force Survey Statistical Release P0210, September 2006.
} 
masse. In addition, Black Africans have flowed steadily into the labor force over the past decade and continue to do so. The new entrants to the labor force changed not only the unemployment rate, but also the composition of the unemployment pool because they had lower skill levels and less work experience due to Apartheid-era employment restrictions. These new entrants to the labor market still have not been fully absorbed into the workforce. While unemployment rates have declined slightly since 2003, there is no indication that they will be brought down to reasonable levels anytime soon. ${ }^{2}$

Unemployment appears to be particularly sticky: many individuals are unable or unwilling to extricate themselves from it. Moreover, in the Labour Force Survey (LFS) panel over 60 percent of the unemployed have never held a job before, including many adults under 35 years old. The stickiness of unemployment results in many South Africans being unemployed for long stretches of time, and the duration of unemployment is generally highest for Black Africans. Stephan Klasen and Ingrid Woolard (2009) find that only about 3 percent of the unemployed are receiving unemployment support at any point in time. Having such a small portion of the unemployed receiving government income raises the question of how the unemployed are supporting themselves.

In the absence of a formal unemployment support system targeted at the

\footnotetext{
${ }^{2}$ South African Labour Force Survey Data.
} 
unemployed, households and families provide an important form of social insurance. Earned and unearned income of other household members is an important source of support for the unemployed during an extended period of job search or discouragement, acting as a private safety net. This is particularly important in Southern Africa where it is common to share resources among extended family networks. This paper contributes to the literature examining mechanisms households use to cope with income shocks including spending down household wealth (Angus Deaton, 1992), reallocating leisure across time, increasing household size to exploit economies of scale, deferring consumption on semi-durables (Elizabeth Frankenberg, James P. Smith, and Duncan Thomas, 2003), sending children to be fostered (Richard Akresh, 2009), increasing school enrollment, delaying fertility, reallocating household consumption (David J. McKenzie, 2003) and accessing microfinance institutions (Paul Gertler, David I. Levine and Enrico Moretti, 2009).

In South Africa, the elderly share their pensions with kin networks in the expectation of being supported in times of need (Andreas Sagner and Raymond Z. Mtati 1999). A number of studies have shown that pension income to one household member is generally shared within the household, which can alter labor supply (Marianne Bertrand, Sendhil Mullainathan and Douglas L. Miller 2003), affect transfers from migrants (Robert T. Jensen 2003), enhance household security (Elisabeth Ardington and Frances Lund 1995) and change the allocation of household income to food, schooling and 
savings (Anne Case and Angus Deaton 1998). Esther Duflo (2003) demonstrates that the allocation of pension income depends on the gender of the pension recipient. ${ }^{3}$ Household composition also responds to changes in pension income. Amar Hamoudi and Duncan Thomas (2005) demonstrate that individuals with lower levels of human capital tend to co-reside with pensioneligible adults while Cally Ardington, Anne Case and Victoria Hosegood (2009) found that the pension allows household members to migrate to find work, specifically by providing resources to support search. Like pensioners, employed members of the household will generally take on the burden of financially supporting unemployed household members.

While many studies have documented the impact of pension income on labor market outcomes and the allocation of household resources, we know comparatively little about the impact of changes in earned income on these outcomes. This study examines how households respond to a reduction in earned household income following a job separation and sheds light on the mechanisms through which households cope in an environment of high and persistent unemployment. Just as changes in welfare and unemployment benefits have effects on labor market outcomes, changes in household earned income will affect reservation wages and labor supply decisions of its members. In this paper I first examine the effect of a household member's job

\footnotetext{
${ }^{3}$ The tight kin network of exchanges and obligations has also been documented among black urban poor near Chicago, Illinois (Carol Stack, 1974).
} 
separation on the labor market outcomes of other members of the household. I look for evidence of a response akin to what Woytinsky called the added worker effect: "the familiar story of the head of the family losing his job whereupon his wife and children also start looking for work" (Don D. Humphrey 1940). A decrease in household income will decrease the value of the outside option causing the reservation wage to fall, search effort to increase and unemployment duration to decrease. Second, I examine other mechanisms for coping with temporary or permanent reductions in household wage income including accessing other sources of financial support, altering the composition of the household, drawing down assets and obtaining access to credit.

This is one of the first papers to use newly available LFS household panel data with existing cross-sectional LFS data which contains information about all household members (see Banerjee, Abhijit, Sebastian Galiani, James Levinsohn, Zoë McLaren and Ingrid Woolard, 2008; Vimal Ranchhod and Taryn Dinkelman, 2008). The linked data allow me to assemble a comprehensive picture of household labor market dynamics and the crosssectional characteristics that drive them.

A job separation or reduction in the wage of one household member affects the desired labor supply of other members of the household whether or not 
this translates into observable changes in labor supply. ${ }^{4}$ Tim Maloney (1987) identifies the two pathways through which the added worker effect operates: the income effect and the cross-substitution effect. A reduction in household income decreases per capita income for each member of the household. In response, individuals shift away from leisure, and increase their labor supply and search effort. This effect would be particularly pronounced if households prefer increased labor supply to dissaving or incurring debt, or if the latter options are infeasible (as is the case for most Black African households in South Africa). The positive cross-substitution effect arises when a household member takes over some home production activities after he or she loses a job or has their hours reduced (Maloney 1987). This lowers the shadow wage for home production for other unemployed or underemployed household members (i.e. the outside option, in the job search literature), which lowers the reservation wage and leads them to increase their labor supply. ${ }^{5}$ The added worker effect may also operate through an increase in motivation to find employment due to pressure from or altruism towards other household members.

There is a rich literature examining the added worker effect in the United States (see James J. Heckman and Thomas E. MaCurdy (1980, 1982), Doki

\footnotetext{
${ }^{4}$ This holds whether the household is modeled as a unitary decision-maker or as a set of actors with bargaining power (Kaushik Basu, Garance Genicot and Joseph E. Stiglitz 1999), provided that bargaining power over household resources is greater than zero for all household members.

${ }^{5}$ I do not attempt to distinguish the relative size of the income effect and the crosssubstitution effect in this paper. Both effects lower the reservation wage.
} 
Tano (1993), James R. Spletzer (1997), Melvin Stephens (2002) and Chinhui Juhn and Simon Potter (2007)). Using the Panel Study on Income Dynamics (PSID), W. Jean Yeung and Sandra L. Hofferth (1998) find a marginally statistically significant added worker effect for black families in the U.S., noting that homeowners and families in areas with high unemployment were least likely to increase work hours. Shelly Lundberg (1985) finds that the added worker effect is most evident among white families, whereas in black (and to a lesser extent Hispanic) families employment outcomes of husbands and wives are positively related rather than negatively related as the added worker effect predicts. She suggests positive assortative mating based on similar tastes or market opportunities as the underlying explanation. Richard Layard, M. Barton and Antonio Zabalza (1980) find that women with unemployed husbands are substantially less likely to work than those with employed husbands. They suggest that the crowding out effect of unemployment insurance and the deterioration of local labor market conditions account for their results.

There is a more limited literature on the added worker effect internationally. Reynaldo Fernandes and Fabiana de Felício (2002) find an added worker effect in Brazil that is larger than the U.S. estimates; they attribute the magnitude to liquidity constraints that prevent families from smoothing temporary income shocks. Similarly, other studies in Turkey (Cem Baslevent and Özlem Onaran, 2003) and Mexico (Susan W. Parker and Emmanuel Sk- 
oufias, 2004) have found the added worker effect to be more pronounced during times of economic crisis when credit constraints are most binding. Pieter Serneels (2002) finds no added worker effect in Ethiopia in terms either employment or desired labor supply and concludes that it is because families were able to sell assets or employ consumption smoothing.

The added worker effect is primarily defined as influencing desired labor supply, which may or may not translate into an observable change in employment. Maloney (1987) stresses that the added worker effect may not be evident in the data because actual hours of work are desired hours censored at zero. This issue is further compounded in South Africa where structural and frictional causes of unemployment undoubtedly prevent job seekers from translating desired hours into employment in many cases.

In this paper, I investigate whether there is any evidence that a job separation in the household is associated with an increased likelihood that nonemployed household members find work, non-participating household members join the active labor market, or enrolled students leave school as the added worker effect predicts. Given the potentially limited importance of the added worker effect in such a high-unemployment environment, I also examine household adjustments in response to a household job separation including changes in household composition, spending down assets or obtaining credit or loans. My analysis focuses on Black African households 
because Black Africans compose over 80 percent of the South African population, their unemployment rate is very high, and kin support networks are generally strong. Unsurprisingly, I find no evidence of an added worker effect among either men or women. Neither increases employment nor labor market attachment in the year following a job separation; the point estimates for employment are in fact negative. I find evidence that household composition is less likely to change following a job separation, except in households that contain a pension-eligible member. My results also show that households have lower household expenditure, fewer financial assets and more food insecurity in the wake of a job separation.

The outline of my paper is as follows: Section 2 describes new Labour Force Survey data that for the first time allows researchers to track a nationallyrepresentative sample of individuals over time. Section 3 presents descriptive statistics that compare households that have experienced a recent job separation with those that have not. I also include transition matrices to compare employment outcomes for Black Africans and Whites. I present my regression methods in Section 4 and my results in Section 5. Section 6 concludes. 


\section{The Data}

This study uses the South Africa Labour Force Survey (LFS), which is equivalent to the United States Current Population Survey (CPS) except that the LFS is conducted only twice a year and it uses a rotating sample where 20 percent of households are replaced each round. The LFS was conducted biannually by Statistics South Africa (StatsSA) between March 2000 and September 2007, with the first wave of each year in March, and the second wave in September. Each wave of the nationally representative sample consists of about 100,000 individuals in about 30,000 households. Detailed information was collected about the labor market situation of individuals aged 15-65 years, focusing on the preceding seven days. The LFS questionnaire includes questions about demographic characteristics, biographical information, activities related to work, unemployment and non-economic activities, agricultural activities and uncompensated activities. ${ }^{6}$

I link the new confidential household panel data with the public-use crosssectional data using confidential match identification numbers that allow me to determine household characteristics for all individuals in the panel data. The LFS suffers from the same limitations of the CPS in that households are not followed if they leave the original dwelling place which results in attrition due to mobility. Franco Peracchi and Finis Welch (1993), however,

\footnotetext{
${ }^{6}$ More information is available at http://www.statssa.gov.za.
} 
find no evidence of systematic bias in the estimates of labor force transitions in the matched CPS sample. One important advantage of the LFS is that individuals remain in the sample beyond the maximum panel length of the CPS matched sample.

Using standard International Labour Organization (ILO) definitions, individuals were classified as employed (in either the formal or the informal sector), unemployed or not economically active (NEA) based on responses to a series of survey questions. The methodology is summarized in Table 1. Respondents were employed if they had performed a job activity in the past 7 days, or if they were absent from a job due to bad weather, or due to personal leave to care for their own illness or that of a family member. Respondents were unemployed if they could not find work, or if they had a job but were absent due to transport problems, a layoff or another reason not mentioned above. They had to be willing to accept a suitable job if it were offered and be ready to start work within one week to be classified as unemployed. The respondent was also considered unemployed if he or she had a job that started at a definite date in the future. Within the unemployed, a respondent was classified as searching if they had taken active steps to look for work or to start their own business in the four weeks prior to the interview, and classified as discouraged otherwise. Individuals were classified as NEA if they had another primary activity (i.e. student, homemaker, retired) and they preferred not to work. Seasonal workers in the off-season were also 
considered NEA.

Table 1: Employment status based on responses to Labour Force Survey questions

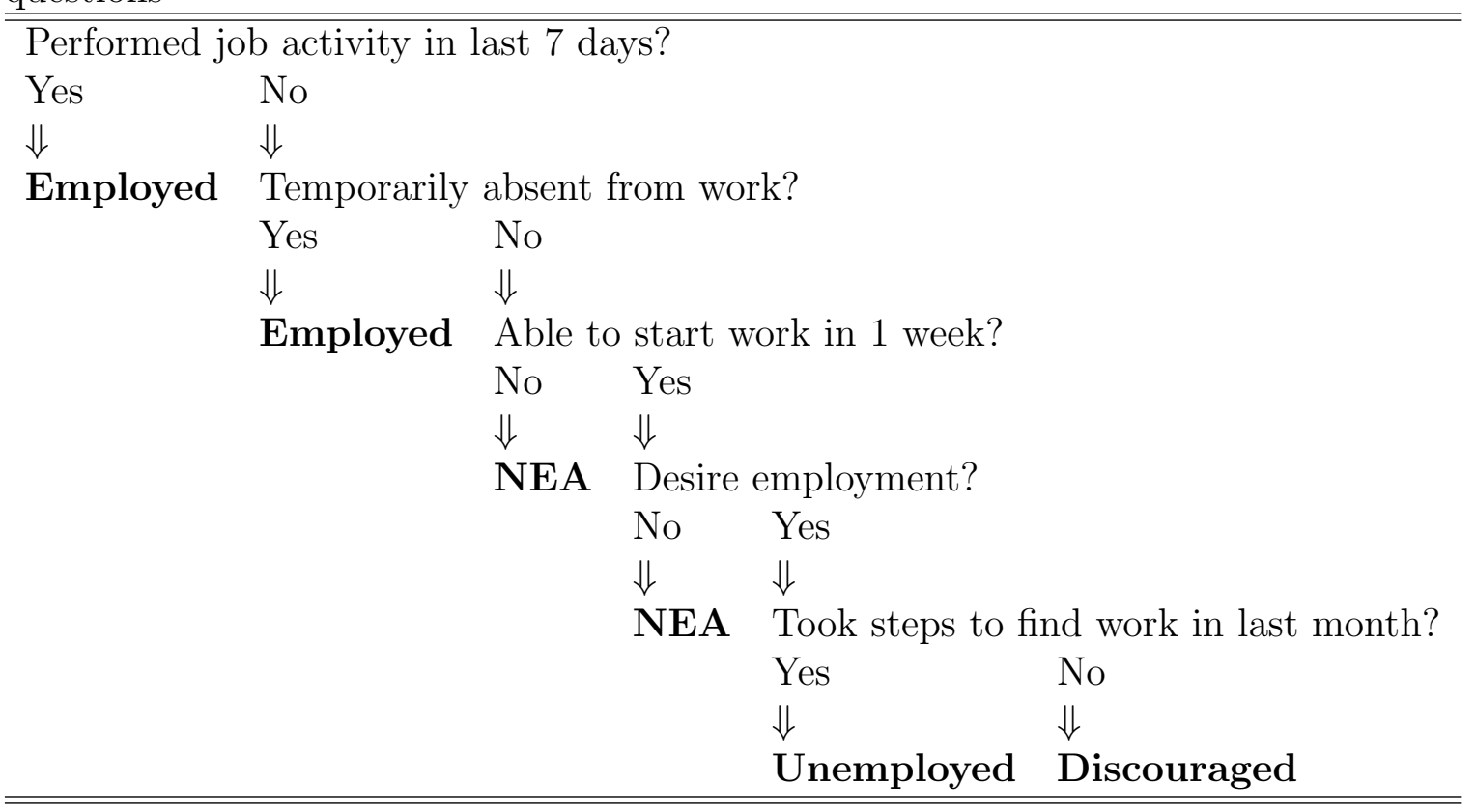

I included discouraged workers in my analysis even though they are not included in the official (ILO) definition of unemployment because discouragement is not an absorbing state in South Africa. The transition rate between discouragement and employment is over 10 percent for Black Africans. Discouraged workers may begin searching and obtain employment within the six months elapsing between survey waves. Also, the offer arrival rate for discouraged workers may not be zero. The unemployed will not search in periods where there are not enough resources to cover search costs, but if funds become available (e.g. savings accumulate) they may resume searching. 
The results in this paper are based on individual-level data from waves 4 through 9 of the LFS, as released by StatsSA. From September 2001 (wave 4) to March 2004 (wave 9), the sample involved a rotating panel design, with 20 percent of respondents being rotated out between waves. Considerable effort on the part of StatsSA created a panel of individuals who were present in two or more cross-sectional waves(see Table 2). The panel sample size ranges between 45,000 and 71,000 individuals out of a possible maximum of 80,000 matches due to the rotating panel design. ${ }^{7}$ These rates are comparable to the 71 percent overall match rate for the CPS which employs a similar survey and respondent-following methodology (Brigitte C. Madrian and Lars John Lefgren, 2000). As in the CPS, the panel data suffers from attrition due to non-response (individual or household level), mortality, migration or recording errors. I perform inverse probability weighting (IPW) based on the CPS IPW methodology to correct for differential attrition on observables (see Appendix Table 12). As another robustness check, I conducted a sensitivity analysis, which I discuss below, to confirm that results are consistent across samples subject to different levels of attrition from the panel (see Appendix tables).$^{8}$

\footnotetext{
${ }^{7}$ Detailed information about the matching process is available in StatsSA (2006).

${ }^{8}$ The individual (person) weights provided by StatsSA and used in this analysis correct for household non-response.
} 
Table 2: Labour Force Survey sample sizes by wave

\begin{tabular}{ccccc}
\hline \hline Date & Wave & \multicolumn{2}{c}{ Sample size } & \% in panel \\
& & Panel & X-section & \\
\hline Sep 2001 & 4 & 60,639 & 106,439 & 71 \\
Mar 2002 & 5 & 71,153 & 109,410 & 81 \\
Sep 2002 & 6 & 68,050 & 102,480 & 83 \\
Mar 2003 & 7 & 66,825 & 100,834 & 83 \\
Sep 2003 & 8 & 58,756 & 98,748 & 74 \\
Mar 2004 & 9 & 45,856 & 98,256 & 58 \\
\hline
\end{tabular}

Due to rotating panel design where 20 percent of sample was rotated out each wave, the panel inclusion rate is out of a maximum of 80 percent of the cross-sectional sample.

Table 3: Transition matrices for men by race

\begin{tabular}{lcccccc} 
Black African men & \multicolumn{7}{c}{ Mar 2004 } \\
Sept 2003 & NEA & Discouraged & Searching & Employed & Total & $N$ \\
\hline NEA & 75.41 & 8.74 & 9.36 & 6.49 & 100 & 1,840 \\
Discouraged & 19.34 & 35.98 & 25.29 & 19.39 & 100 & 661 \\
Searching & 14.80 & 17.03 & 45.65 & 22.52 & 100 & 999 \\
Employed & 4.32 & 4.68 & 9.10 & 81.90 & 100 & 2,584 \\
Total & 28.29 & 11.40 & 17.12 & 43.19 & 100 & 6,084 \\
\hline \hline
\end{tabular}

White men

Mar 2004

Sept $2003 \quad$ NEA Discouraged Searching Employed Total $N$

\begin{tabular}{lcccccc}
\hline NEA & 76.83 & 0.31 & 1.60 & 21.25 & 100 & 124 \\
Discouraged & 11.14 & 12.74 & 17.55 & 58.57 & 100 & 8 \\
Searching & 8.26 & 5.62 & 37.58 & 48.55 & 100 & 26 \\
Employed & 4.63 & 0.99 & 1.57 & 92.82 & 100 & 805 \\
Total & 12.61 & 1.13 & 2.39 & 83.88 & 100 & 963 \\
\hline
\end{tabular}

Sample includes ages 16-64. All values are weighted. Value in cell is proportion of individuals in row category in September 2003 who transitioned into column category by March 2004. Transition rates are broadly representative of other waves in panel. Source: Labour Force Survey panel data, wave 8 and wave 9 . 
Table 4: Transition matrices for women by race

\begin{tabular}{lcccccc}
\multicolumn{2}{l}{ Black African women } & \multicolumn{5}{c}{ Mar 2004 } \\
Sept 2003 & NEA & Discouraged & Searching & Employed & Total & $N$ \\
\hline NEA & 63.31 & 16.24 & 11.75 & 8.70 & 100 & 2,411 \\
Discouraged & 24.49 & 38.12 & 25.10 & 12.29 & 100 & 1,266 \\
Searching & 20.97 & 21.81 & 42.46 & 14.76 & 100 & 1,192 \\
Employed & 10.33 & 6.25 & 10.07 & 73.35 & 100 & 2,316 \\
Total & 32.30 & 18.20 & 19.00 & 30.49 & 100 & 7,185 \\
\hline \hline
\end{tabular}

White women

Mar 2004

\begin{tabular}{lcccccc} 
Sept 2003 & NEA & Discouraged & Searching & Employed & Total & $N$ \\
\hline NEA & 83.44 & 1.86 & 3.79 & 10.91 & 100 & 289 \\
Discouraged & 12.81 & 20.00 & 17.36 & 49.83 & 100 & 14 \\
Searching & 43.34 & 14.34 & 28.69 & 13.62 & 100 & 26 \\
Employed & 8.85 & 0.75 & 2.34 & 88.05 & 100 & 619 \\
Total & 31.55 & 1.61 & 3.53 & 63.31 & 100 & 948 \\
\hline
\end{tabular}

Sample includes ages 16-64. All values are weighted. Value in cell is proportion of individuals in row category in September 2003 who transitioned into column category by March 2004. Transition rates are broadly representative of other waves in panel. Source: Labour Force Survey panel data, wave 8 and wave 9 . 


\section{Descriptive Statistics}

Tables 3 and 4 compare transition rates for men and women, respectively, between four employment categories: not economically active (NEA), discouraged, searching and employed (informal and formal sectors combined). The other two racial categories, Indians and Coloureds, are omitted but their employment outcomes tend to fall between those of Black Africans and Whites. The value in each cell is the proportion of individuals in the row category in September 2003 (wave 8) who transitioned into the column category by March 2004 (wave 9); these transition rates are broadly representative of the rates between the other LFS panel waves. Two things are immediately evident from the transition matrices. First, discouragement is a particularly sticky employment category for Black Africans compared to Whites. Over 35 percent of Black Africans who are discouraged remain so six months later, whereas this figure is only about 13 percent for White men, and 20 percent for White women. Clearly the duration of unemployment varies by race. Second, a similar proportion of Black African men and women transition from discouragement to employed as transition from unemployed to employed within the six months that elapses between waves. Discouragement is not an absorbing state and is clearly distinct from NEA based on the transition rates. Following Christopher J. Flinn and James J. Heckman (1983) and Füsun Gönül (1992) it makes sense to consider discouraged workers when examin-

ing the added worker effect in Black African households. Geeta Kingdon and 
John Knight (2006) perform a series of comparisons of searching and nonsearching unemployed and concludes that search is hindered by constraints rather than tastes in South Africa. This provides additional support for considering discouraged workers as distinct from being out of the labor force.

In my central analysis I use the incidence of one or more job separations within the household to investigate the added worker effect. Table 5 compares households in which at least one household member experienced a job separation with households in which no one did. The first two columns present sample means, Column 3 shows the difference in means, Column 4 shows the difference expressed as a percentage and Column 5 shows the t-statistic on the difference in means conditional on the other covariates included in the main regression results (see Section 4). The main differences between the two samples are that households that experience a job separation are slightly larger with more employed members and are more likely to be in receipt of the child grant. Though other coefficients are statistically significant in such a large sample, the difference (in absolute value or percentage terms) is relatively small. 
Table 5: Means of covariates: Did someone in the household transition to unemployment 6 to 12 months ago?

\begin{tabular}{lccccc}
\hline Variable & $\begin{array}{c}\text { Yes } \\
\text { Mean }\end{array}$ & $\begin{array}{c}\text { No } \\
\text { Mean }\end{array}$ & Diff. & $\begin{array}{c}\text { Diff. } \\
(\%)\end{array}$ & $\begin{array}{c}\text { t-statistic } \\
\text { with controls }\end{array}$ \\
\hline \hline Job separation 6-12 months earlier & 0.02 & 0.02 & 0.00 & 0.00 & -2.8 \\
Number of employed men in hhold & 0.85 & 0.26 & 0.59 & 0.69 & 15.3 \\
Number of employed women in hhold & 0.81 & 0.21 & 0.60 & 0.74 & 15.7 \\
Never held a job & 0.26 & 0.22 & 0.04 & 0.15 & -4.2 \\
Local unemployment rate & 0.45 & 0.25 & 0.20 & 0.44 & 0.7 \\
Pension eligible in household & 0.14 & 0.08 & 0.06 & 0.43 & 2.6 \\
Household receives child grant & 0.20 & 0.06 & 0.14 & 0.70 & 5.0 \\
Number of adults in hhold & 1.72 & 1.42 & 0.30 & 0.17 & 2.8 \\
Number of children in hhold & 1.84 & 1.52 & 0.32 & 0.17 & 0.7 \\
Age & 32.40 & 32.65 & -0.25 & -0.01 & 8.1 \\
Number of household members & 11.56 & 11.97 & -0.41 & -0.04 & -9.3 \\
Yrs. of primary education & 6.24 & 6.09 & 0.15 & 0.02 & -0.8 \\
Yrs. of secondary education & 2.44 & 2.34 & 0.10 & 0.04 & 1.5 \\
Completed Matric (H.S.) & 0.20 & 0.23 & -0.03 & -0.15 & -5.0 \\
Some post-Matric education & 0.02 & 0.03 & -0.01 & -0.50 & -5.8 \\
Number of observations & 1191 & 39523 & & &
\end{tabular}

Sample includes Black Africans ages 16-59 in households that were completely matched for at least one wave, inverse probability weighted. All waves pooled. Specifications include full set of controls listed in table, survey wave dummies and county fixed effects. Standard errors are clustered by household. 


\section{Methods}

The first section of my analysis consists of linear probability regressions of a set of individual labor market outcomes on a vector of individual and household covariates. The preferred specification includes "county"-level (main place) fixed effects and I provide OLS estimates as a comparison. ${ }^{9}$ Regression analysis (at the individual level) is based on the following specification:

$$
Y_{i j t}=\beta_{0}+\beta_{1} \operatorname{Sep}_{\sim i, t}+\beta_{2} \operatorname{Sep}_{\sim i, t-1}+\phi^{\prime} X_{i j t-1}+\delta_{t}+\alpha_{j}+\epsilon_{i j t}
$$

where $Y_{i j t}$ is an outcome variable for individual $i$ in county $j$ for time period $t$, Sep $_{\sim i, t}$ is an indicator for the household experiencing a contemporaneous job separation of a prime age (25-49 year old) household member (other than the respondent), $\operatorname{Sep}_{\sim i, t-1}$ is an indicator for a prime age household job separation in the previous 6 month period, $X_{i j t-1}$ is a vector of lagged individual and household characteristics, $\delta_{t}$ is a set of time dummies (for survey waves) and $\alpha_{j}$ represents county fixed effects. Standard errors are clustered at the household level.

My outcomes of interest include four labor market status outcomes: whether an individual transitioned from broad unemployment (including those who desire work but are not actively searching) to employment (either formal

\footnotetext{
${ }^{9}$ The approximately 3,000 South African "counties" known as main places have a median population of 4,200 and contain no more than 100,000 residents.
} 
or informal), whether an individual transitioned from NEA (does not desire work) or broad unemployment to employment (either formal or informal), whether an individual transitioned from NEA or discouraged into (narrow) labor force participation and whether an individual is currently attending an educational institution. I also examine the usual weekly number of hours worked for individuals who are employed, and whether the individual reports wanting to work more hours per week. For unemployed individuals, I examine changes in the likelihood of reporting their primary source of financial support as: someone in the household, someone outside of the household, pension income or savings.

The $X_{i j t-1}$ vector includes controls for whether at least one household member is of pension eligible age, interactions between pension eligibility and each job separation variable $\left(\operatorname{Sep}_{\sim i, t}\right.$ and $\left.\operatorname{Sep}_{\sim i, t-1}\right)$, the number of employed men in the household (excluding the respondent), the number of employed women in the household (excluding the respondent), whether the respondent had a job separation in the previous period, whether the respondent has ever held a job, whether someone in the household receives a government child grant, age, age-squared, years of primary education, years of secondary education, a dummy for having graduated high school (matric), a dummy for having completed some post-high school education, the number of adults in the household and the number of children under 16 in the household. ${ }^{10} \mathrm{I}$ also

\footnotetext{
${ }^{10}$ The child grant is available to primary caregivers with co-resident children under 18.
} 
control for the county-level local race- and sex-specific unemployment rate (calculated excluding the respondent).

For the second section of the analysis I collapse the data to one observation per household and perform identical regressions using the same control variables calculated at the household level as well as county fixed effects. For the household, my outcomes of interest are whether the composition of the household changed between waves (calculated conservatively so that recording errors leading to panel exclusion would show up as a change in composition), the number of pension-aged adults (women 60 and above, men 65 and above), whether total household expenditure was in a lower bracket than the previous 6 months, whether the household reported having problems satisfying household food needs often or always in the past year, whether any household member reported owning any kind of financial assets (including savings or life insurance), and whether any household member reported receiving cash loans or buying on credit in the last year.

Though my sample includes Black Africans aged 16-59, I only examine the impact of job separations of 25-49 year olds to exclude anticipated and voluntary job separations due to retirement or students returning to school after employment during school breaks. I perform separate regressions for men and women because household job separations surely affect the labor supply of each gender differently. Observations from all six panel waves were 
pooled in the regression, and standard errors are clustered at the household level. Following U.S. CPS methodology, I use inverse probability weighting by survey wave for inclusion in the panel to correct for differential attrition.

I evaluate the robustness of my results to different sample restrictions. My primary sample is restricted to individuals in households that are fully matched in at least one wave. In the appendix tables, I compare my main results with results obtained using three different samples (a) a less restrictive sample consisting of individuals that are in households where at least 50 percent of the household is matched (and therefore included in the panel) in

the current wave, (b) a more restrictive sample of individuals in households that are fully matched (i.e. where every member is in the panel) for three consecutive waves spanning one year, and (c) a sample of "stayers" who are in at least 4 waves (spanning 18 months) of the panel. The appendix also compares results with and without inverse probability weighting.

\section{$5 \quad$ Results}

The results in Table 6 show no evidence of an added worker effect among Black African men or women when I examine transitions either from broad unemployment (either searching or not) to employment (either formal or informal) or when I expand the analysis to include transitions from not economically active (NEA) (i.e. not working and don't desire employment) to 
employment. Point estimates are negative rather than positive as the added worker effect predicts. The first four columns show results for men with and without the inclusion of county fixed effects, and the second four columns show results for women.

For the preferred specification in Column 2 that includes county fixed effects, a job separation of a prime age member of the household (other than the respondent) during the last 6 months is associated with a reduction of 1.4 percentage points in the likelihood of transition to employment for men and a job separation 6-12 months earlier is associated with a reduction of 2.4 percentage points, however neither of these point estimates is statistically significant. In households that contain a pension-eligible member I find a 6.1 percentage point decrease in the likelihood of employment transition. There is no relationship between transition and intra-household job separations when I expand the analysis to include transitions from either NEA or unemployment to employment (Columns 3 and 4). Appendix Tables 13 and 14 show these results are consistent across samples and weights.

For women, I find no association between a job separation in the household and a transition from unemployment to employment. Point estimates, though robust to changes in sample and weights, are small with large standard errors. In households that contain a pension-eligible member, job separations either within 6 months or 6-12 months earlier are associated with 
a 1.0 and 1.4 percentage point reduction in the likelihood of transitions, respectively, though these estimates are not statistically significant. The presence of a pension-aged household member reduces the likelihood by a statistically-significant 4.9 percentage points. There is no effect when expanding the sample to include transitions between NEA and employment (Columns 7 and 8).

Table 7 shows results for transitions into narrow labor force participation and into school or training enrollment. In response to a household job separation, the added worker effect predicts that individuals will be drawn into the labor force from retirement, home production or school enrollment. Column 2 shows that men are no more likely to become labor force participants after a job separation in the household. This likely reflects that non-participating men are either positively selected (enrolled in school) or negatively selected (ill-suited for employment or disinclined to be employed) and would only consider entering the labor force once other avenues for income replacement had been exhausted. Though pension income has been shown to support and induce job search, in this case men are a statistically significant 2.8 percentage points less likely to transition when a pension-age member of the household is present. Column 4 shows that there is no relationship between recent job separation and the likelihood of school enrollment.

Column 6 of Table 7 shows that women are 2 percentage points less likely 
to join the labor force within 6 months of a job separation in the household, and 4.1 percentage points less likely to make the transition 6-12 months following a job separation. These results are robust but not statistically significant at the $5 \%$ level. There is a weak positive relationship between job separations and school enrollment for women, but it is not statisticallysignificant. ${ }^{11}$

Because I do not observe a positive association between job separations and transitions to employment, as the added worker effect predicts, it raises the question of whether there are other adjustments made by household members to attempt to replace lost household income after a household job separation. Employed workers may increase their work hours in response to a shock, exhibiting the added worker effect on the intensive margin and mitigating the effect we observe for non-employed household members on the extensive margin. Columns 1 and 2 of Table 8 show no relationship between a recent job separation and the usual number of weekly hours worked by men or women. ${ }^{12}$ Column 4 shows that women are 6.5 percentage points more likely to report wanting more weekly hours of work in the 6 months following an intra-household job separation, but not more likely in the 6-12 months

\footnotetext{
${ }^{11}$ As expected, estimates of the relationship between labor force participation and a job separation 6-12 months earlier are negative and statistically significant for the least restrictive sample since this sample includes households with members that migrated in or out of the household (Appendix Table 20

${ }^{12}$ Appendix Table 21 shows that the one exception is that in the most restrictive sample limited to households with no composition changes in three consecutive waves we see a statistically-significant increase of 4 hours for men in response to a recent job separation.
} 
following. Such a short timeline is consistent with one characterization of the added worker effect - that women in husband-wife pairs obtain a temporary second-best job quickly as a stop-gap measure while other household members seek better employment opportunities. Lundberg (1985) found that female labor supply increased for only two months following the shock and Spletzer (1997) found a small effect contemporaneous to the shock (rather than two months after).

Unemployed respondents were asked to name their primary source of financial support, and Table 9 shows results for regressions of the responses to this question on the set of covariates. For women, a job separation less than 6 months earlier within the household statistically-significantly lowers the likelihood of reporting that someone within the household provides financial support. Unemployed men and women report being financially supported by a household member 6-12 months after a household job separation, which is likely either due to the separated individual finding work or the household dividing existing household income among more household members. Men and women are on average more likely to report receiving financial support from someone outside the household or relying on savings during the first 6 months after a job separation.

Table 10 presents results for regressions run at the household level. Households that experience a job separation are a statistically-significant 10 per- 
centage points less likely to report salaries and wages as the main source of income in the first 6 months, 5.3 percentage points more likely to report pensions as the main source of income and no more likely to report remittances as the main source of income. ${ }^{13}$

Households may exhibit in-migration or out-migration in response to a job separation. Household members may leave the household to improve their employment prospects or to find other sources of financial support. On the other hand, they may recruit employed individuals or pension recipients to join the household and provide support as a substitute for increased labor supply on the part of existing household members. The results in Table 11 show that in fact households are 4.4 percentage points less likely to exhibit a change in composition when there was a recent job separation in the household. ${ }^{14}$ However, households with at least one pension-eligible member are 14.7 percentage points more likely to change composition overall.

Column 2 shows that households with a recent job separation are no more likely to change the number of members of pension age. Households with a recent job separation are 2.3 percentage points more likely to report a decrease in total household expenditure in the first 6 months and 5.5 percentage

\footnotetext{
${ }^{13}$ Appendix Table 35 shows that, as expected, remittances are more likely to be reported in households that experienced a change in composition.

${ }^{14}$ Recall that this is a conservative measure (i.e. overestimate) of changes in composition that includes individuals being excluded from the panel due to non-response, mortality or recording error.
} 
points more likely 6-12 months later. Appendix Table 38 shows that these results hold up even for the sample with no composition change. Columns 4 and 5 show an increase of 4.5 percentage points in the likelihood of reporting problems satisfying their food needs and a decrease of 10 percentage points in the likelihood of having financial assets following a household job separation and pensioners appear to provide no protective effect. There is no relationship between recent job separations and the use of loans or credit.

\section{Discussion}

My findings shed light on how households cope with job separations when the public safety net is limited. I find no evidence of the added worker effect at work in the South African labor market which is unsurprising considering the presence of high and persistent unemployment. Since increasing labor force attachment is not a viable option, households appear to rely on other strategies to replace earned income such as savings, pensions and remittances. I find some evidence that households are worse off after a job separation: households reduce expenditures (even in the absence of household composition changes) and the likelihood of reporting frequent food insecurity increases.

In South Africa, a number of factors related to frictional unemployment 
can prevent individuals from translating labor supply into employment, or even discourage increases in search activity. Finding employment may take time considering the slow employment growth in South Africa and the glut of unemployed individuals. Though we would expect it to be easier to transition into search than into employment, high costs associated with job seeking in South Africa may pose a significant barrier to an individual conducting an active job search. The majority of Black Africans live in residential neighborhoods established under apartheid that are far from business centers and that remain highly segregated (Anthony J. Christopher 2001, 2005). Even informal enterprises are clustered in inner-city zones, and sparser in Black African townships and informal settlement areas where there is less opportunity for economic growth (Christian M. Rogerson, 1996). There are high transportation costs associated with job searching due to the spatial separation and the fact that public transportation infrastructure built under apartheid was designed to serve White areas. Transportation costs account for up to a 10 percent share of consumption for many South Africans (Stephan Klasen, 1997). Additionally, there are high screening costs (due to varying educational quality) and high dismissal costs (legal and administrative obstacles) that require job seekers to invest in the employer's interview and assessment process.

A number of studies including Francis Wilson and Mamphela Ramphele (1989) and Kingdon and Knight (2006) have found that poverty inhibits job 
search in South Africa. The ability to search may reflect the availability of household resources to support the search, rather than imply that the searching worker is more determined to obtain employment (or that their unobserved qualities are better than those who are not searching). The finding that men and women are no more likely to begin or resume job search after a household job separation may reflect the inability to fund an on-going job search immediately following a job separation, despite the fact that desired labor supply may have increased.

In South Africa the discouraged worker effect likely dominates the added worker effect in the short run. Layard, Barton and Zabalza (1980) attribute their inability to find an added worker effect to the fact that it was swamped out by the discouraged worker effect that arises when poor labor market conditions cause market wages to fall for all members of the household, making potential added workers less likely to seek employment. The discouraged worker effect is particularly pronounced during times of economic crisis (Baslevent and Onaran 2003), but can also play a role when local unemployment rates rise (Lundberg 1985, Gruber and Cullen 2000).

Households have viable income replacement strategies to cope with the loss of earned income in the short run, but over the long run job separations are likely to strain these strategies. Improving the design of policy interventions and social insurance programs, and the unemployment benefit in 
particular, would improve the well-being of South African households. It is especially important for the poorest households that are more credit constrained and therefore have access to fewer methods of mitigating the effect of negative shocks. Addressing structural factors in the labor market that constrain an individual's response to a household shock will enable households to respond more quickly to adverse employment events and limit the long term negative repercussions. 


\section{$7 \quad$ References}

Akresh, Richard. 2009. "Flexibility of Household Structure: Child Fostering Decisions in Burkina Faso." Journal of Human Resources 44(4): 976-997.

Ardington, Cally, Anne Case and Victoria Hosegood. 2009. "Labor supply responses to large social transfers: Longitudinal evidence from South Africa." American Economic Journal: Applied Economics, 1(1):22-48.

Ardington, Elisabeth and Frances Lund. 1995 "Pensions and development: social security as complementary to programmes of reconstruction and development." Development Southern Africa, 12 (4): 557-577.

Banerjee, Abhijit, Sebastian Galiani, James Levinsohn, Zoë McLaren and Ingrid Woolard. 2008. "Why Has Unemployment Risen in the New South Africa?" Economics of Transition, 16(4): 715-740.

Baslevent, Cem and Özlem Onaran. 2003 "Are Married Women in Turkey More Likely to Become Added or Discouraged Workers?" Labour, 17: 439458.

Basu, Kaushik, Garance Genicot and Joseph E. Stiglitz. 1999. "Household labour supply, unemployment, and minimum wage." World Bank Policy Research Working Paper 2049. 
Bertrand, Marianne, Sendhil Mullainathan and Douglas L. Miller. 2003. "Public Policy and Extended Families: Evidence from Pensions in South Africa." The World Bank Economic Review, 17 (1): 27-50.

Case, Anne and Angus Deaton. 1998. "Large Cash Transfers to the Elderly in South Africa." Economic Journal, 108: 1330-1363.

Christopher, Anthony J. 2001. "Urban Segregation in Post-apartheid South Africa." Urban Studies, 38(3): 449-466.

Christopher, Anthony J. 2005. "Does South Africa Have Ghettos?" Tijdschrift voor Economische en Sociale Geografie, 96(3): 241-252.

Deaton, Angus. 1992. Understanding Consumption. Oxford: Clarendon Press.

Dinkelman, Taryn. 2004. "How Household Context Affects Search Outcomes of the Unemployed in KwaZulu Natal, South Africa: A Panel Data Analysis." South African Journal of Economics, 72 (3): 484-521.

Duflo, Esther. 2003. "Grandmothers and Granddaughters: Old-Age Pensions and Intrahousehold Allocation in South Africa." The World Bank Eco- 
nomic Review, 17 (1):1-25.

Edmonds, Eric V., Kristin Mammen and Douglas L. Miller. 2005. "Rearranging the family? Income support and elderly living arrangements in a low-income country." Journal of Human Resources, 40(1): 186-207.

Fernandes, Reynaldo and Fabiana de Felício. 2002. "The Entry of the Wife into the Labor Force in Response to the Husband's Unemployment: A Study of the Added Worker Effect in Brazilian Metropolitan Areas." Economic Development and Cultural Change, 53: 887-911.

Flinn, Christopher J. and James J. Heckman. 1983. "Are Unemployment and Out of the Labour Force Behaviourally Distinct Labour Force States." Journal of Labour Economics, 1(1): 28-42.

Frankenberg, Elizabeth, James P. Smith, and Duncan Thomas. 2003. Economic Shocks, Wealth, and Welfare. Journal of Human Resources 38(2):280321.

Gertler, Paul, David I. Levine and Enrico Moretti. 2009. "Do Microfinance Programs Help Families Insure Consumption Against Illness?" Health Economics 18: 257273.

Gönül, Füsun. 1992. "New Evidence on Whether Unemployment and 
Out of the Labour Force are Distinct States." Journal of Human Resources, 27(2): 329-361.

Gruber, Jonathan and Julie B. Cullen. 2000. "Does Unemployment Insurance Crowd out Spousal Labor Supply?" Journal of Labor Economics, 18(3): 546-72.

Hamoudi, Amar and Duncan Thomas. 2005. "Pension Income and the Well-Being of Children and Grandchildren: New Evidence from South Africa." Unpublished.

Heckman, James J. and Thomas E. MaCurdy. 1980. "A Life Cycle Model of Female Labour Supply." Review of Economic Studies, 47(1):47-74.

Heckman, James J. and Thomas E. MaCurdy. 1982. "Corrigendum on a Life Cycle Model of Female Labour Supply." Review of Economic Studies, 49(4): 659-60.

Humphrey, Don D. 1940. "Alleged Additional Workers in the Measurement of Unemployment." Journal of Political Economy, 48: 412-9.

Jensen, Robert T. 2003. "Do Private Transfers Displace the Benefits of Public Transfers? Evidence from South Africa." Journal of Public Eco- 
nomics, 88: 89-112.

Juhn, Chinhui and Simon Potter. 2007. "Is there still an added worker effect?" Federal Reserve Bank of New York Staff Report 310.

Kingdon, Geeta and John Knight. 2006. "The measurement of unemployment when unemployment is high." Labour Economics, 13: 291-315.

Klasen, Stephan. 1997. "Poverty, Inequality and Deprivation in South Africa: An Analysis of the 1993 SALDRU Survey." Social Indicator Research, 41: 51-94.

Klasen, Stephan and Ingrid Woolard. 2009. "Surviving Unemployment without State Support: Unemployment and Household Formation in South Africa." Journal of African Economies, 18(1):1-51.

Layard, Richard, M. Barton, and Antonio Zabalza. 1980. "Married Women's Participation and Hours." Economica, 47 (February): 51-72.

Lundberg, Shelly. 1985. "The Added Worker Effect." Journal of Labor Economics, 3(1): 11-37.

Madrian, Brigitte C. and Lars John Lefgren. 2000. "An approach to lon- 
gitudinally matching Current Population Survey (CPS) respondents." Journal of Economic and Social Measurement 26(1): 31-62.

Magruder, Jeremy R. 2010. "Intergenerational Networks, Unemployment, and Persistent Inequality in South Africa." American Economic Journal: Applied Economics, 2(1): 62-85.

Maloney, Tim. 1987. "Employment Constraints and the Labor Supply of Married Women: A Reexamination of the Added Worker Effect." Journal of Human Resources, 22(1): 51-61.

Maloney, Tim. 1991. "Unobserved Variables and the Elusive Added Worker Effect." Economica, 58(230): 173-87.

McKenzie, David J. 2003. "How do Households Cope with Aggregate Shocks? Evidence from the Mexican Peso Crisis." World Development 31(7): 11791199.

Nattrass, Nicoli and Richard Walker. 2005. "Unemployment and Reservation Wages in Working-Class Cape Town." South African Journal of Economics, 73(3):498-509.

Parker, Susan W. and Emmanuel Skoufias. 2004. "The added worker 
effect over the business cycle: evidence from urban Mexico." Applied Economics Letters, 11(10): 625-630.

Peracchi, Franco and Finis Welch. 1993. "Trends in Labor Force Transitions of Older Men and Women." Journal of Labor Economics, 12(2): 210242.

Ranchhod, Vimal. 2009. "Household responses to adverse income shocks: Pensioner out-migration and mortality in South Africa." Economic Research South Africa Working Paper 113.

Ranchhod, Vimal and Taryn Dinkelman. 2008. "Labour Market Transitions in South Africa: What can we learn from matched Labour Force Survey data?" Southern Africa Labour and Development Research Unit Working Paper 14. Cape Town: SALDRU, University of Cape Town.

Rogerson, Christian M. 1996. "Urban poverty and the informal economy in South Africa's economic heartland." Environment and Urbanization, 8(1): 167-179.

Sagner, Andreas and Raymond Z. Mtati. 1999. Politics of pension sharing in urban South Africa. Ageing and Society, 19: 393-416. 
Serneels, Pieter. 2002. "The Added Worker Effect and Intrahousehold Aspects of Unemployment." Centre for the Study of African Economies Working Paper 2002-14.

Spletzer, James R. 1997. "Reexamining the Added Worker Effect." Economic Inquiry, 35(2): 417-27.

Stack, Carol. 1974. All Our Kin: Strategies for Survival in a Black Community. New York: Harper and Row.

Statistics South Africa, National Statistics System Division. 2006. Measurement, Standards and Capacity Assessment, The South African Labour Force Panel Study Methodology Document.

Stephens, Melvin. 2002. "Worker Displacement and the Added Worker Effect." Journal of Labor Economics, 20: 504-537.

Tano, Doki K. 1993. "The added worker effect: A causality test." Economics Letters, 43:111-117.

Wilson, Francis and Mamphela Ramphele. 1989. Uprooting Poverty: The South African Challenge. London: W.W. Norton \& Co. 
Wittenberg, Martin. 2002. "Job search in South Africa: A non-parametric analysis." South African Journal of Economics, 70 (8): 1163-97.

Yeung, W. Jean and Sandra L. Hofferth. 1998. "Family adaptations to income and jobloss in the US." Journal of Family and Economic Issues, 19: 255-83. 


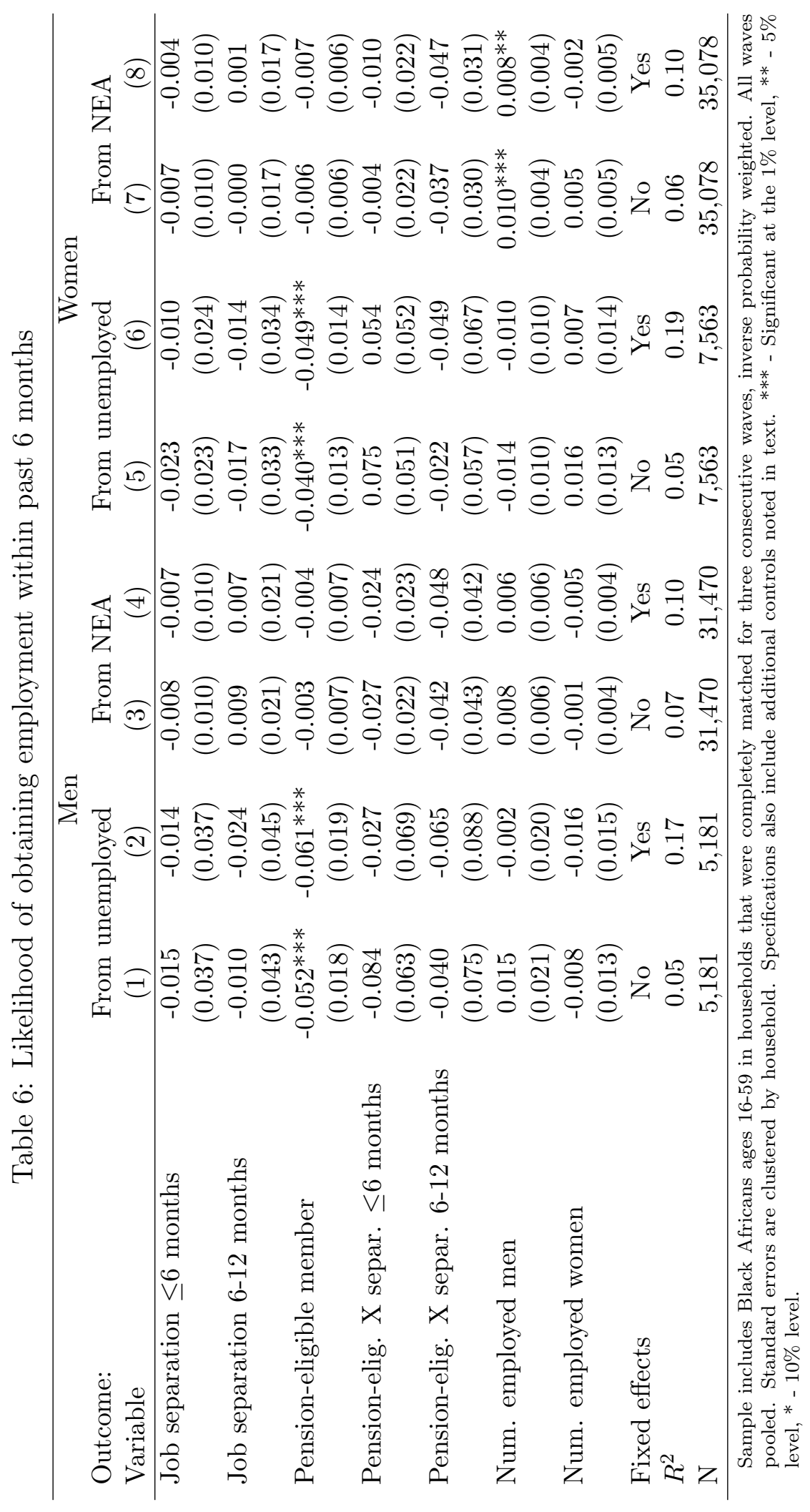




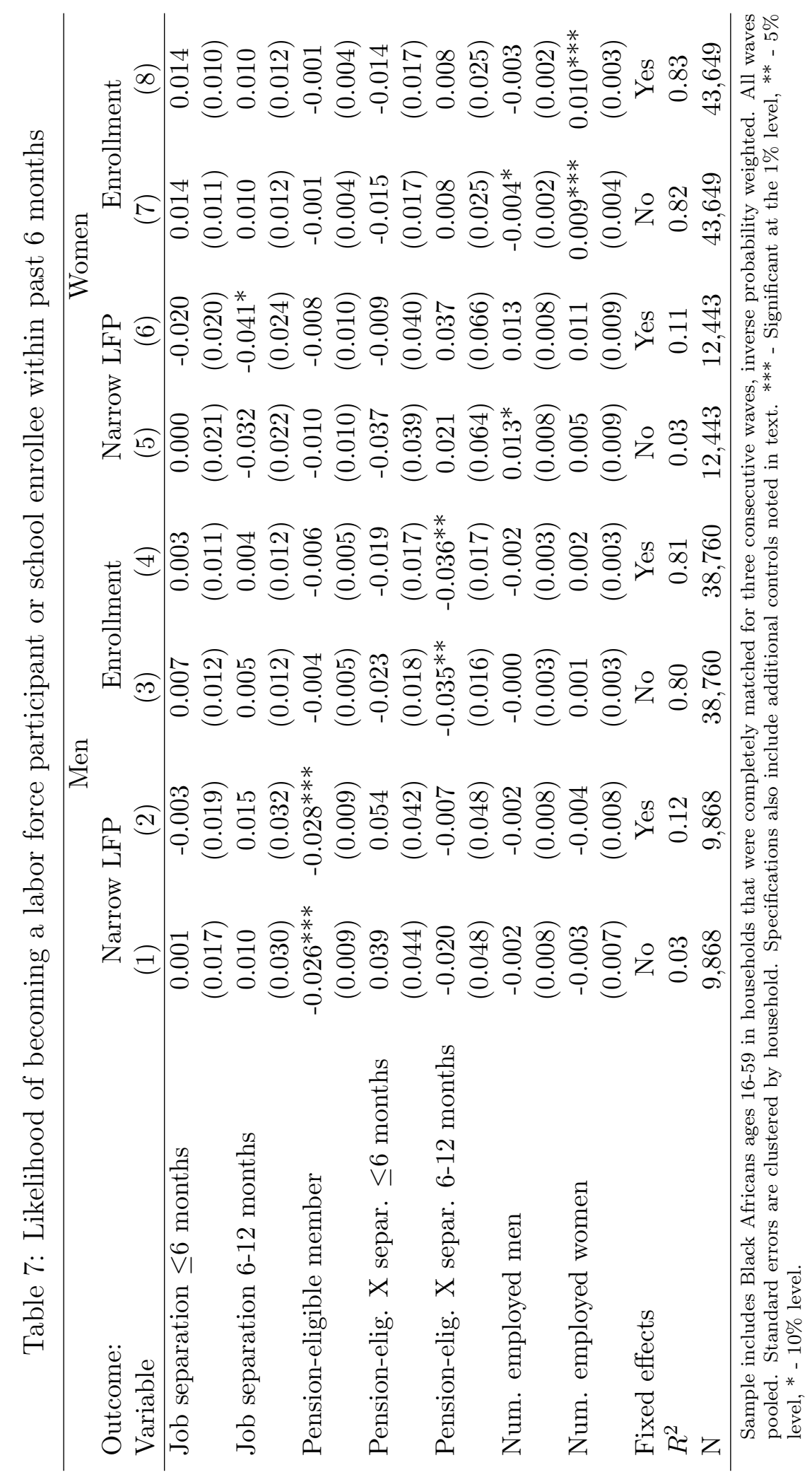


Table 8: Likelihood of working more hours or desiring more work within past 6 months (for employed household members)

\begin{tabular}{lcccc}
\hline Outcome: & \multicolumn{2}{c}{ Weekly work hours } & \multicolumn{2}{c}{ Desire more hours } \\
& Men & Women & Men & Women \\
Variable & $(1)$ & $(2)$ & $(3)$ & $(4)$ \\
\hline Job separation $\leq 6$ months & -0.435 & 0.734 & -0.009 & $0.065^{* *}$ \\
& $(0.927)$ & $(1.293)$ & $(0.024)$ & $(0.032)$ \\
Job separation 6-12 months & -0.405 & -1.786 & 0.070 & -0.013 \\
& $(1.875)$ & $(1.794)$ & $(0.047)$ & $(0.046)$ \\
Pension-eligible member & -1.223 & -0.559 & 0.019 & 0.000 \\
& $(0.942)$ & $(1.066)$ & $(0.022)$ & $(0.023)$ \\
Pension-elig. X separ. $\leq 6$ months & -0.181 & $9.823^{*}$ & 0.096 & 0.040 \\
& $(3.224)$ & $(5.741)$ & $(0.121)$ & $(0.094)$ \\
Pension-elig. X separ. 6-12 months & 7.003 & 3.318 & $-0.187^{*}$ & 0.018 \\
& $(8.572)$ & $(3.184)$ & $(0.101)$ & $(0.110)$ \\
Num. employed men & -0.452 & $-0.899^{* *}$ & $-0.042^{* * *}$ & $-0.025^{* * *}$ \\
\multirow{2}{*}{ Num. employed women } & $(0.391)$ & $(0.412)$ & $(0.011)$ & $(0.009)$ \\
& -0.366 & -0.213 & 0.001 & -0.019 \\
$R^{2}$ & $(0.382)$ & $(0.640)$ & $(0.010)$ & $(0.015)$ \\
N & 0.13 & 0.14 & 0.12 & 0.12 \\
\hline
\end{tabular}

Sample includes Black Africans ages 16-59 in households that were completely matched for three consecutive waves, inverse probability weighted. County fixed effects included. All waves pooled. Standard errors are clustered by household. Specifications also include additional controls noted in text. *** Significant at the $1 \%$ level, ${ }^{* *}-5 \%$ level, ${ }^{*}-10 \%$ level. 


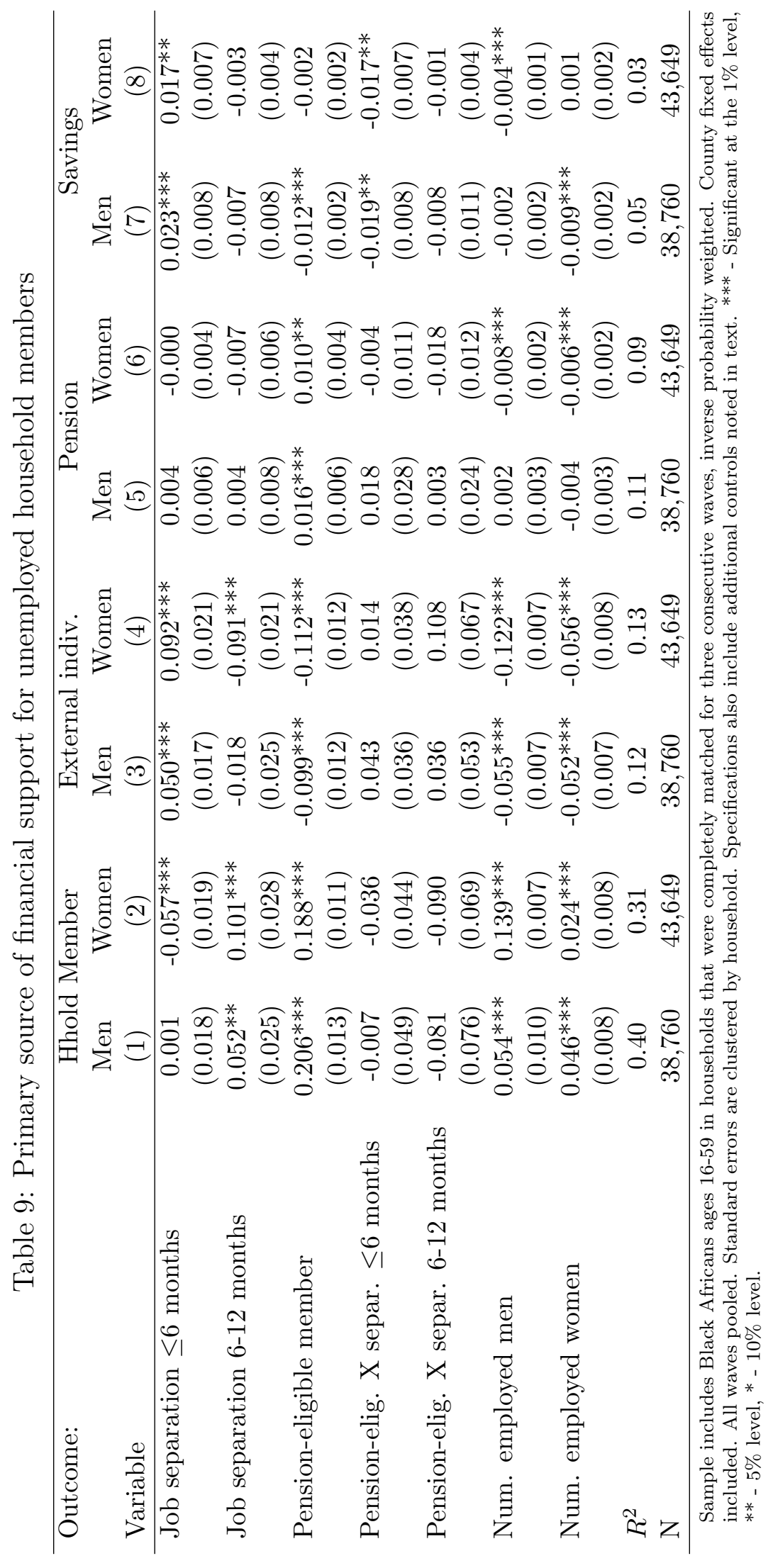


Table 10: Main source of household income

\begin{tabular}{lccc}
\hline Main source of income: & $\begin{array}{c}\text { Salaries } \\
\text { Variable }\end{array}$ & $\begin{array}{c}\text { Remittances } \\
(1)\end{array}$ & $\begin{array}{c}\text { Pensions } \\
(3)\end{array}$ \\
\hline Job separation $\leq 6$ months & $-0.100^{* * *}$ & $0.053^{* * *}$ & 0.010 \\
& $(0.019)$ & $(0.013)$ & $(0.012)$ \\
Job separation 6-12 months & -0.029 & -0.005 & 0.011 \\
& $(0.025)$ & $(0.016)$ & $(0.025)$ \\
Pension-eligible member & $-0.195^{* * *}$ & $0.529^{* * *}$ & $-0.221^{* * *}$ \\
& $(0.014)$ & $(0.014)$ & $(0.010)$ \\
Pension-elig. X separ. $\leq 6$ months & -0.052 & $-0.107^{*}$ & $0.166^{* * *}$ \\
& $(0.061)$ & $(0.055)$ & $(0.027)$ \\
Pension-elig. X separ. 6-12 months & -0.002 & 0.012 & -0.031 \\
& $(0.072)$ & $(0.079)$ & $(0.034)$ \\
Num. employed men & $0.287^{* * *}$ & $-0.080^{* * *}$ & $-0.122^{* * *}$ \\
& $(0.016)$ & $(0.008)$ & $(0.009)$ \\
Num. employed women & $0.226^{* * *}$ & $-0.079^{* * *}$ & $-0.094^{* * *}$ \\
& $(0.013)$ & $(0.008)$ & $(0.008)$ \\
$R^{2}$ & 0.33 & 0.29 & 0.20 \\
N & 37,583 & 37,583 & 37,583 \\
\hline Sample includes Black Africans ages 16-59 in households that were completely matched for three \\
consecutive waves, inverse probability weighted. County fixed effects included. All waves pooled. \\
Specifications also include additional controls noted in text. *** - Significant at the 1\% level, \\
$* *$ - 5\% level, * - 10\% level.
\end{tabular}




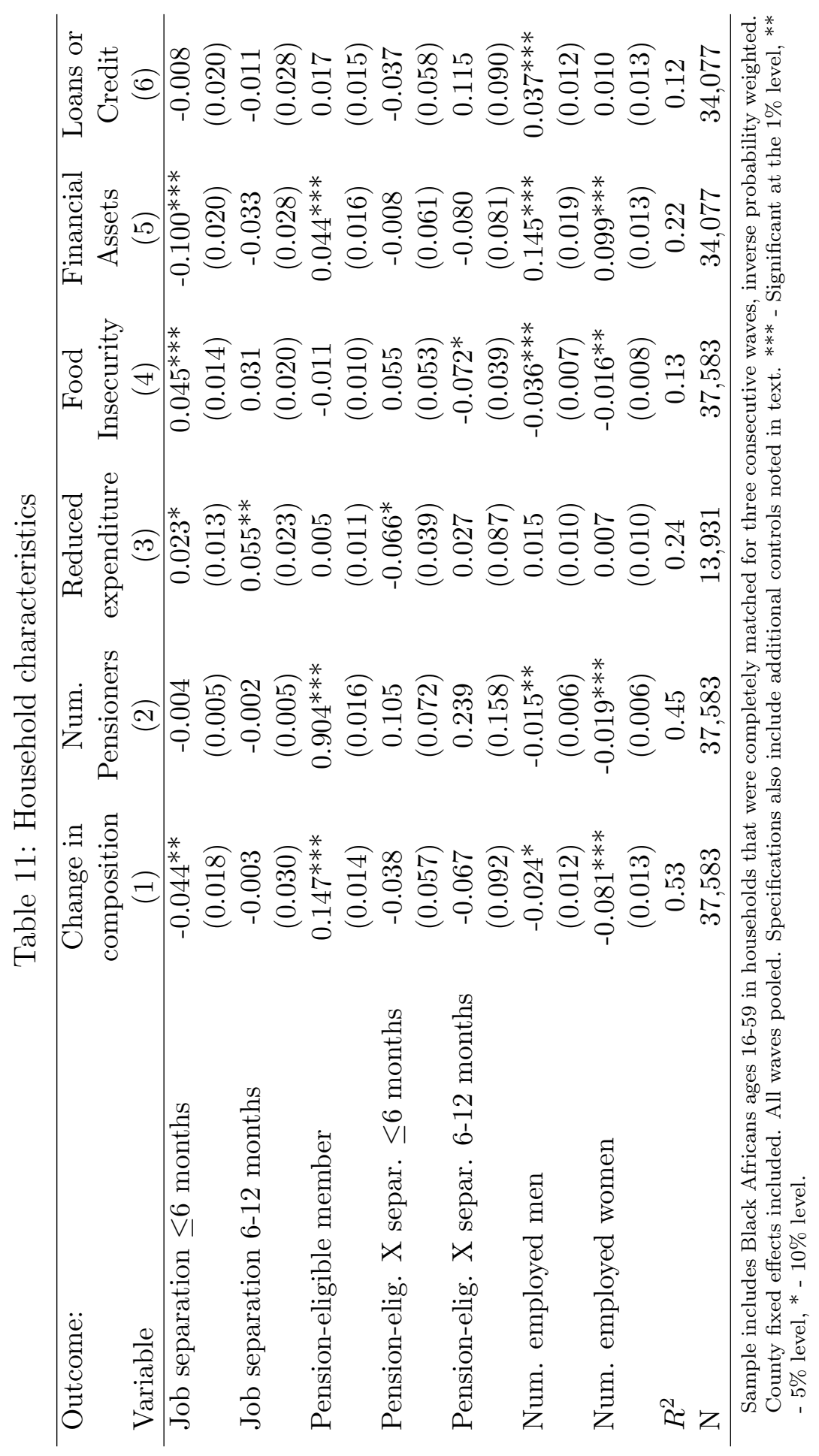


8 Appendix Tables 
Table 12: Likelihood of being included in panel data (for Africans aged 16-64).

\begin{tabular}{lcc}
\hline Variable & Men & Women \\
\hline \hline Urban & $0.174^{* * *}$ & $0.103^{* * *}$ \\
Years of primary school completed & $(0.039)$ & $(0.038)$ \\
& $0.018^{* *}$ & $0.015^{*}$ \\
Years of secondary school completed & $(0.009)$ & $(0.008)$ \\
& $0.051^{* * *}$ & $0.053^{* * *}$ \\
Holds a matric qualification & $(0.014)$ & $(0.013)$ \\
& $-0.108^{*}$ & -0.074 \\
Completed some post-matric education & $(0.060)$ & $(0.056)$ \\
& $0.264^{* *}$ & 0.137 \\
Widowed & $(0.131)$ & $(0.122)$ \\
& -0.218 & -0.062 \\
Divorced & $(0.142)$ & $(0.061)$ \\
& $-0.204^{*}$ & $-0.149^{*}$ \\
Never married & $(0.108)$ & $(0.079)$ \\
& $-0.094^{* *}$ & $-0.119^{* * *}$ \\
Age 15-19 & $(0.044)$ & $(0.037)$ \\
& -0.005 & -0.050 \\
Age 20-24 & $(0.105)$ & $(0.086)$ \\
Age 25-29 & $-0.343^{* * *}$ & $-0.372^{* * *}$ \\
& $(0.106)$ & $(0.085)$ \\
Age 30-34 & $-0.474^{* * *}$ & $-0.265^{* * *}$ \\
& $(0.104)$ & $(0.084)$ \\
Age 35-39 & $-0.457^{* * *}$ & $-0.243^{* * *}$ \\
Age 40-44 & $(0.103)$ & $(0.083)$ \\
Age 45-49 & $-0.306^{* * *}$ & -0.089 \\
Age 50-54 & $(0.102)$ & $(0.083)$ \\
Age 55-59 & $-0.171^{*}$ & -0.042 \\
& $(0.102)$ & $(0.084)$ \\
Constant & -0.107 & 0.048 \\
Observations & $(0.105)$ & $(0.085)$ \\
& -0.044 & 0.059 \\
& $(0.109)$ & $(0.088)$ \\
& -0.132 & 0.113 \\
& $(0.114)$ & $(0.096)$ \\
& 0.102 & 0.006 \\
& $(0.136)$ & $(0.118)$ \\
& 22,922 & 26,279 \\
\hline & & \\
& & \\
& &
\end{tabular}

Samples include Black Africans ages 16-59. Wave 4 only; representative of results from other survey waves. Magisterial district dummies included. *** - Significant at the $1 \%$ level, ** - $5 \%$ level, * - $10 \%$ level. 


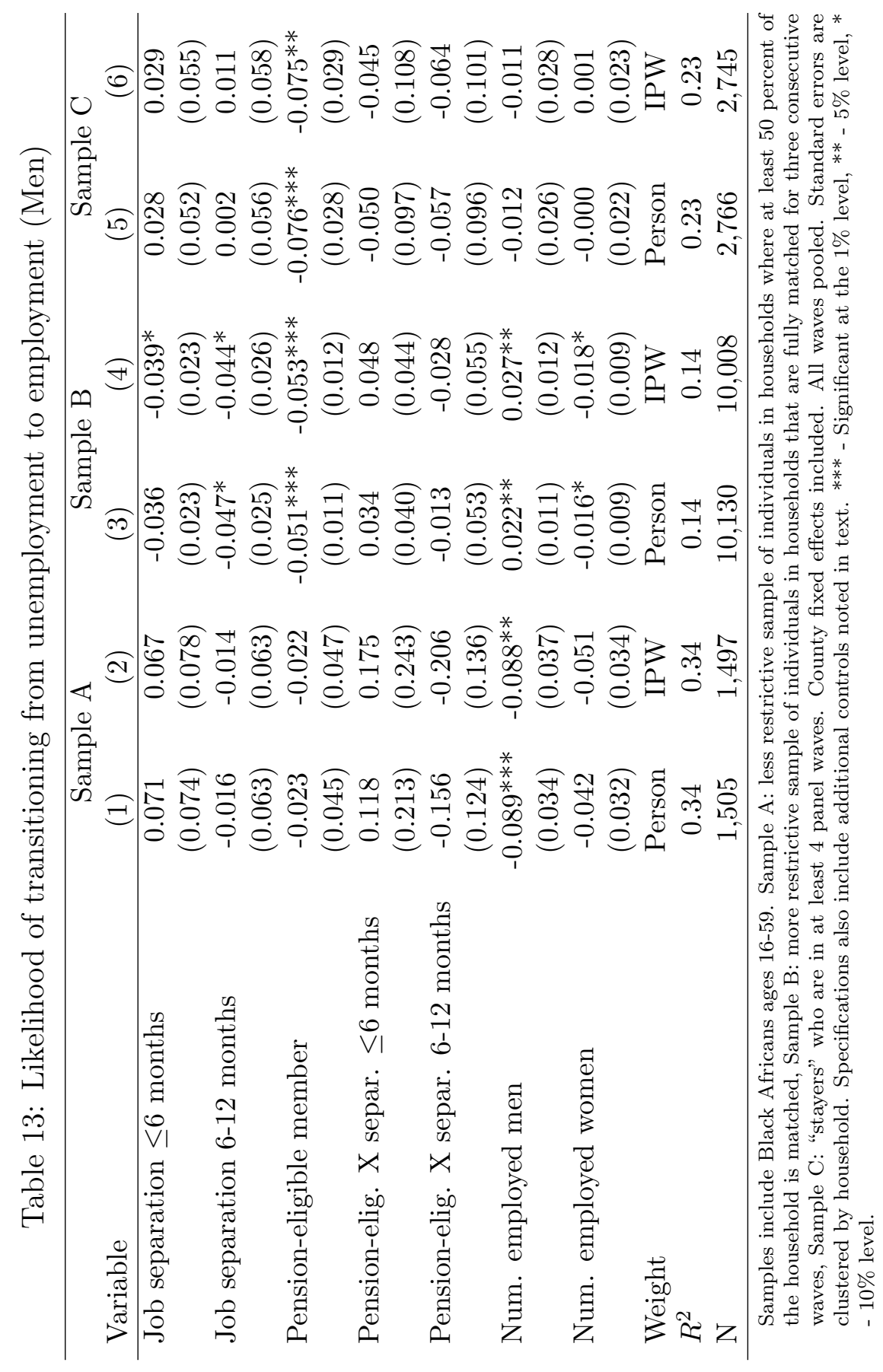




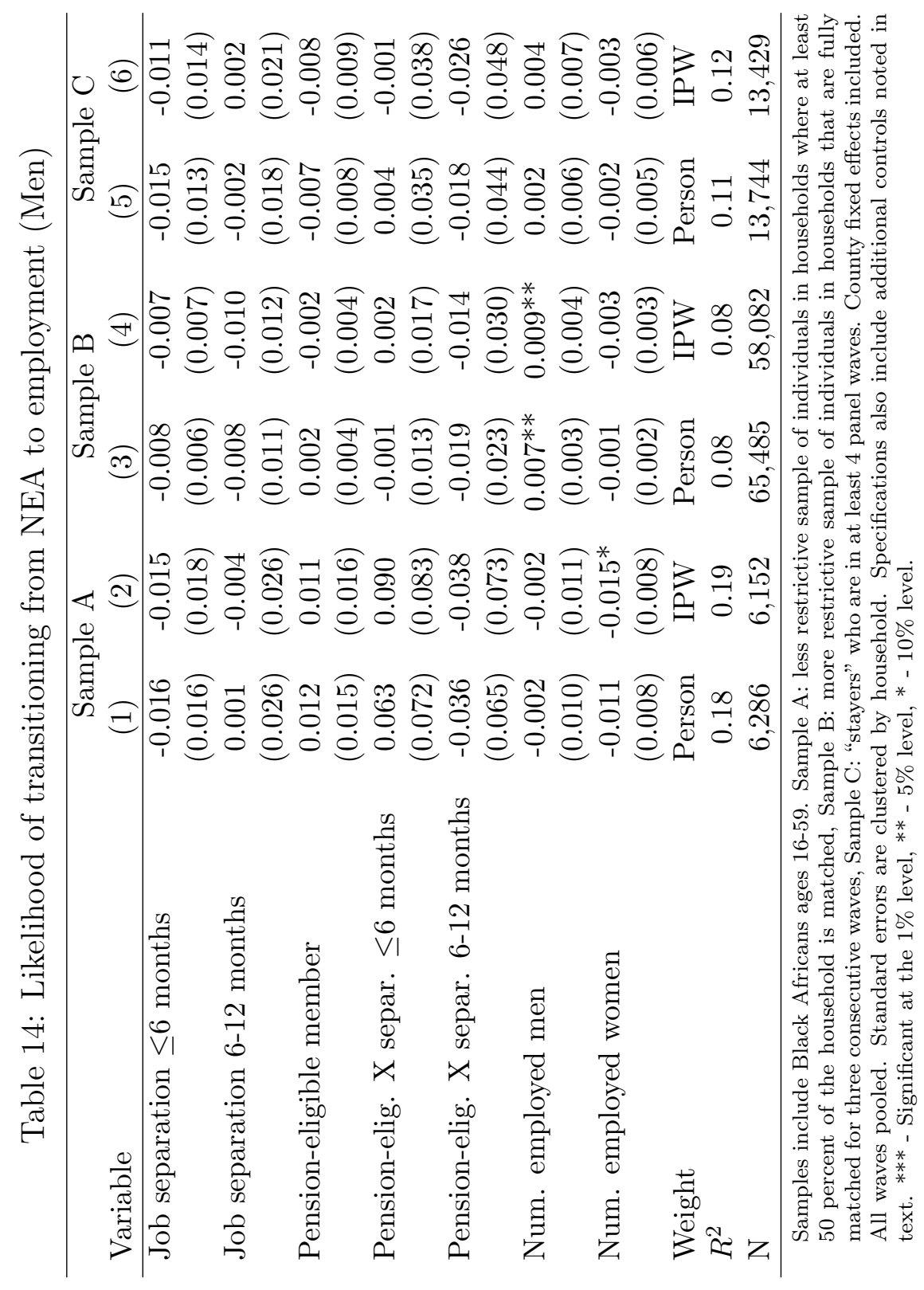




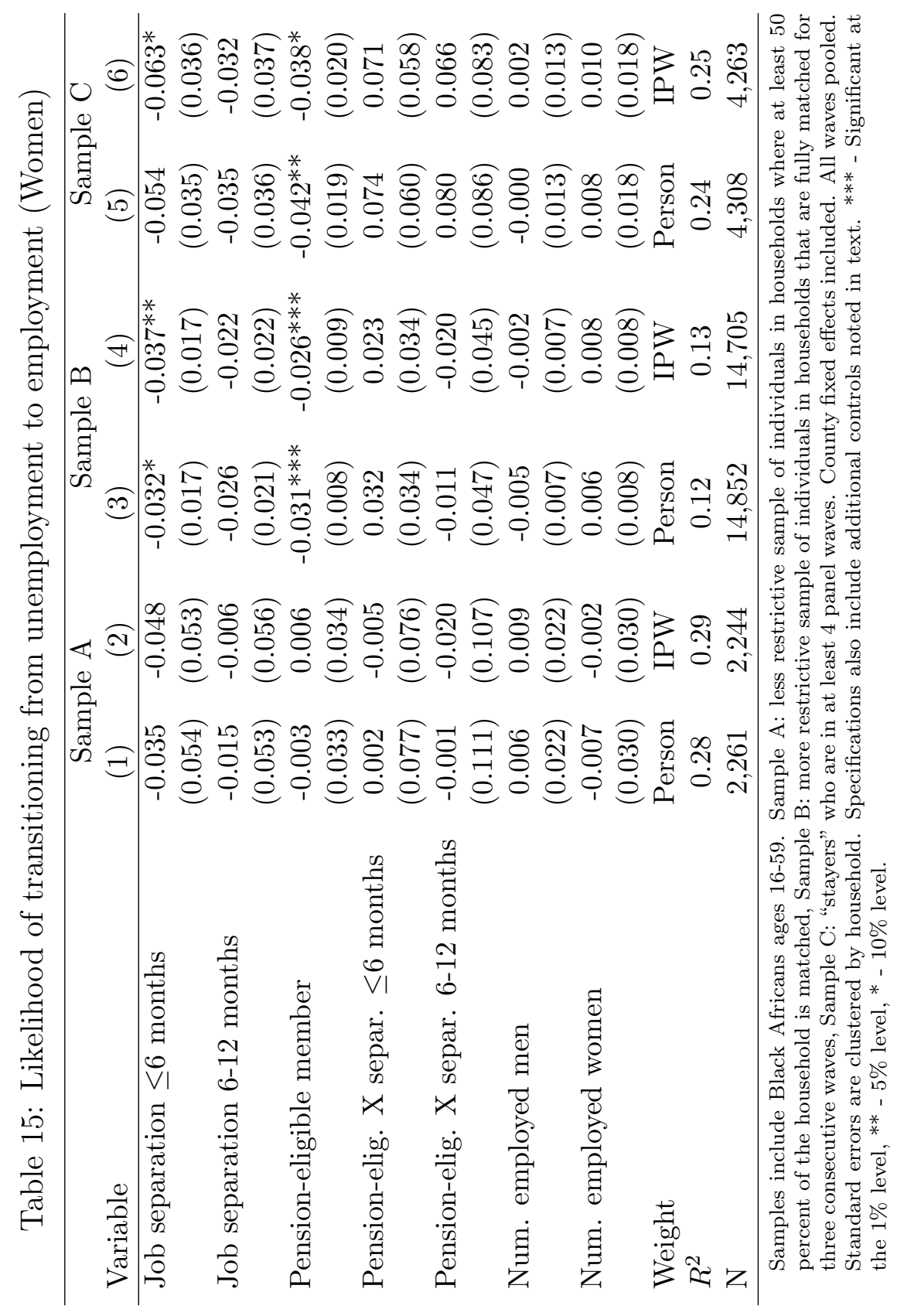




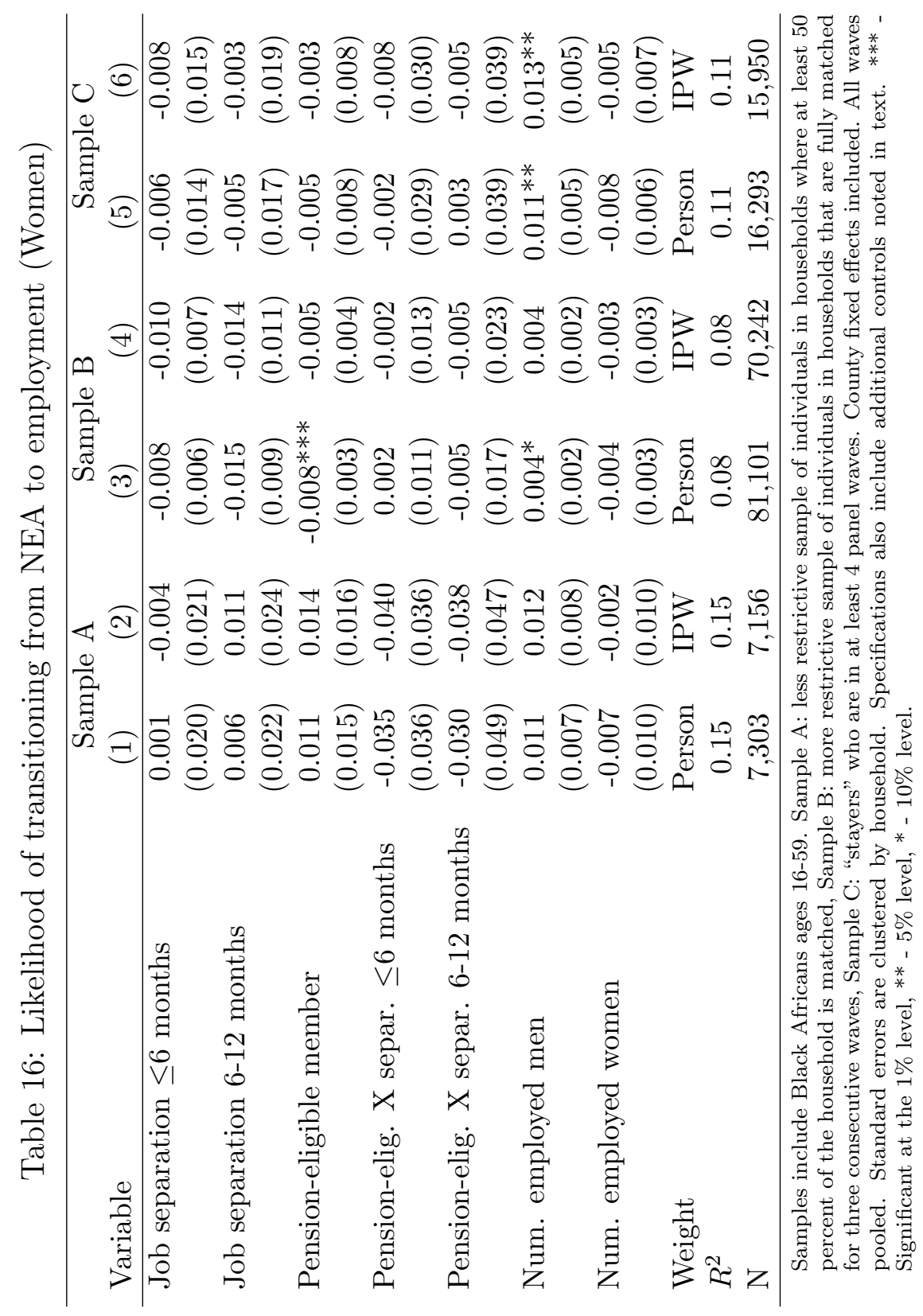




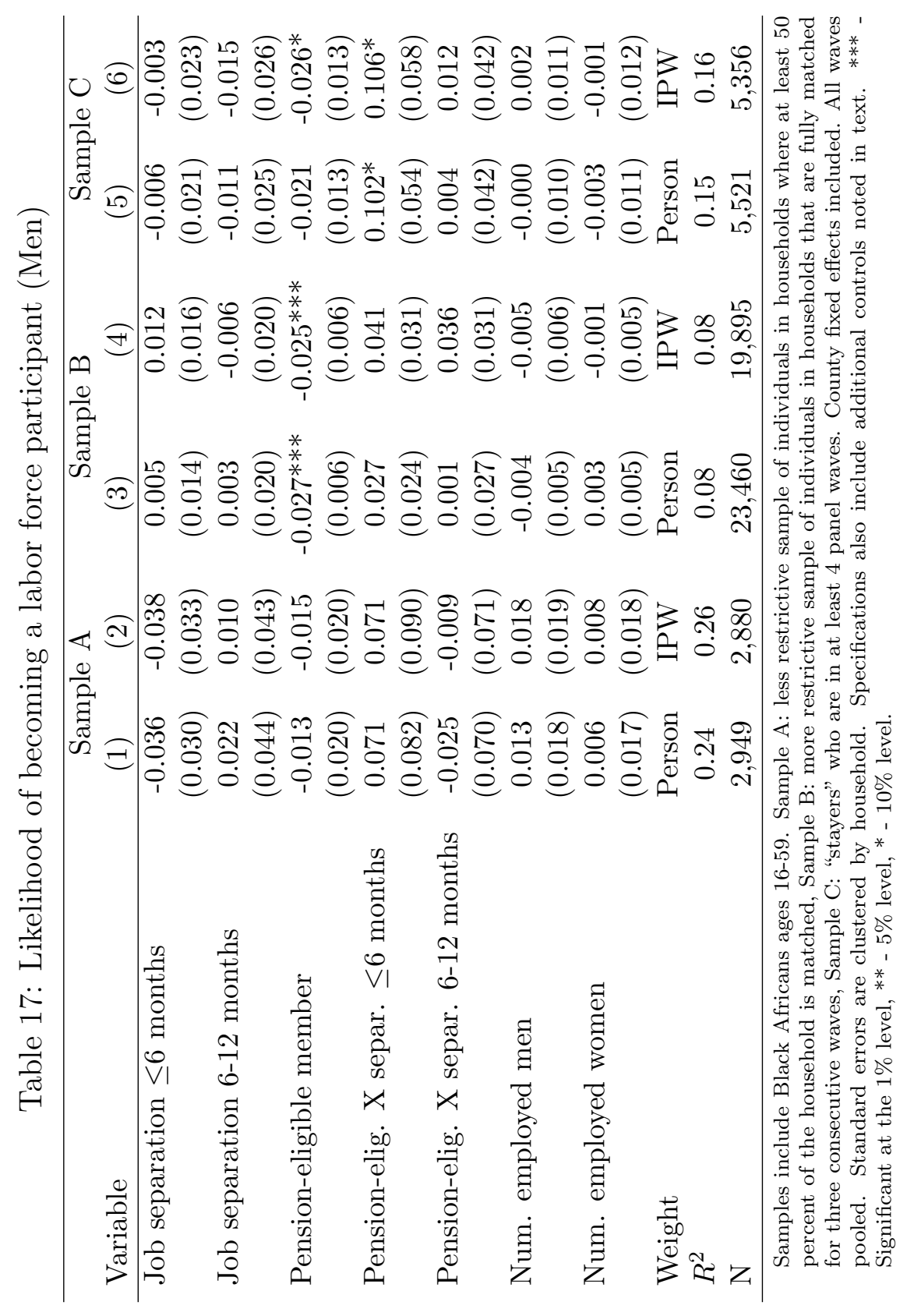




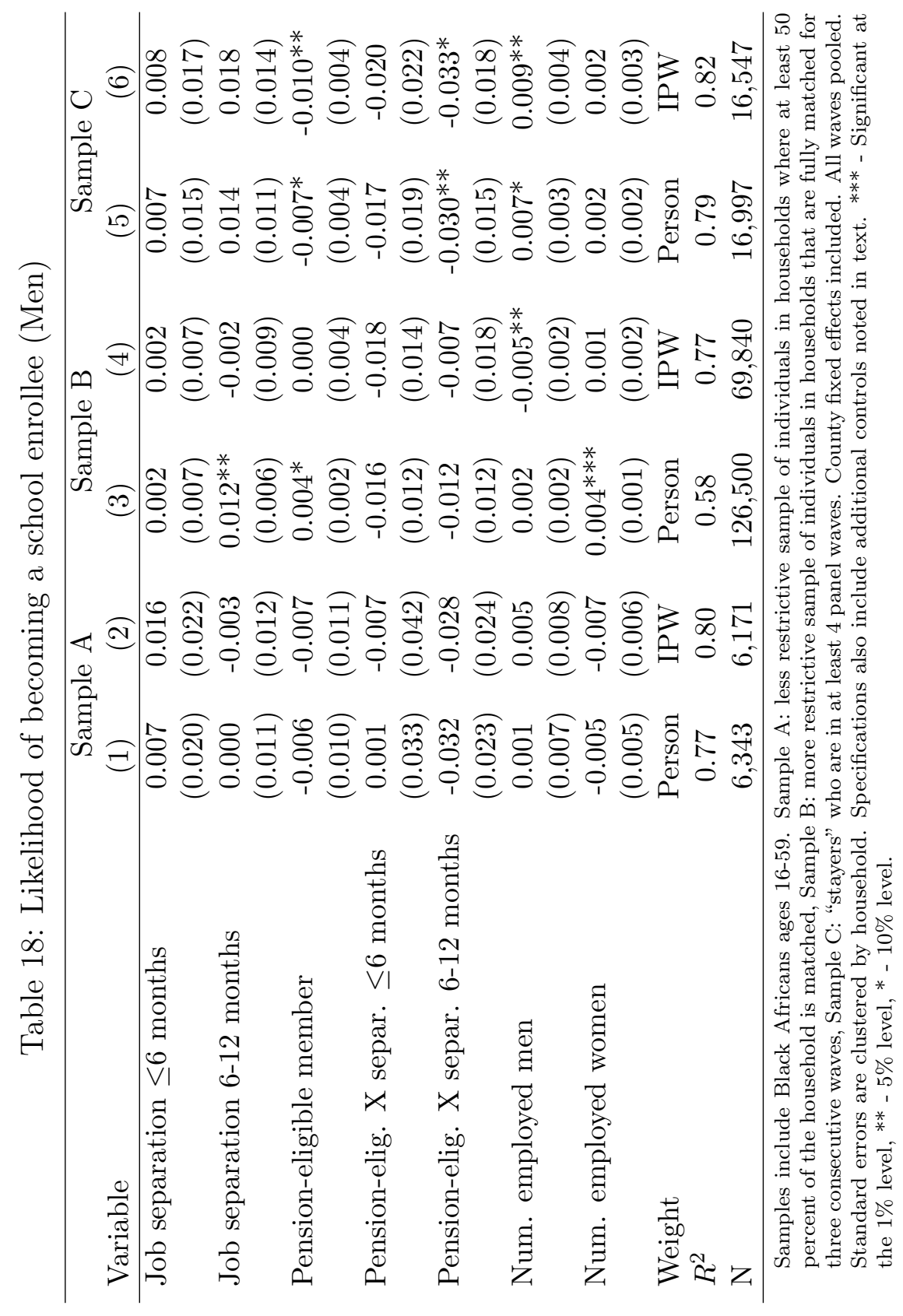




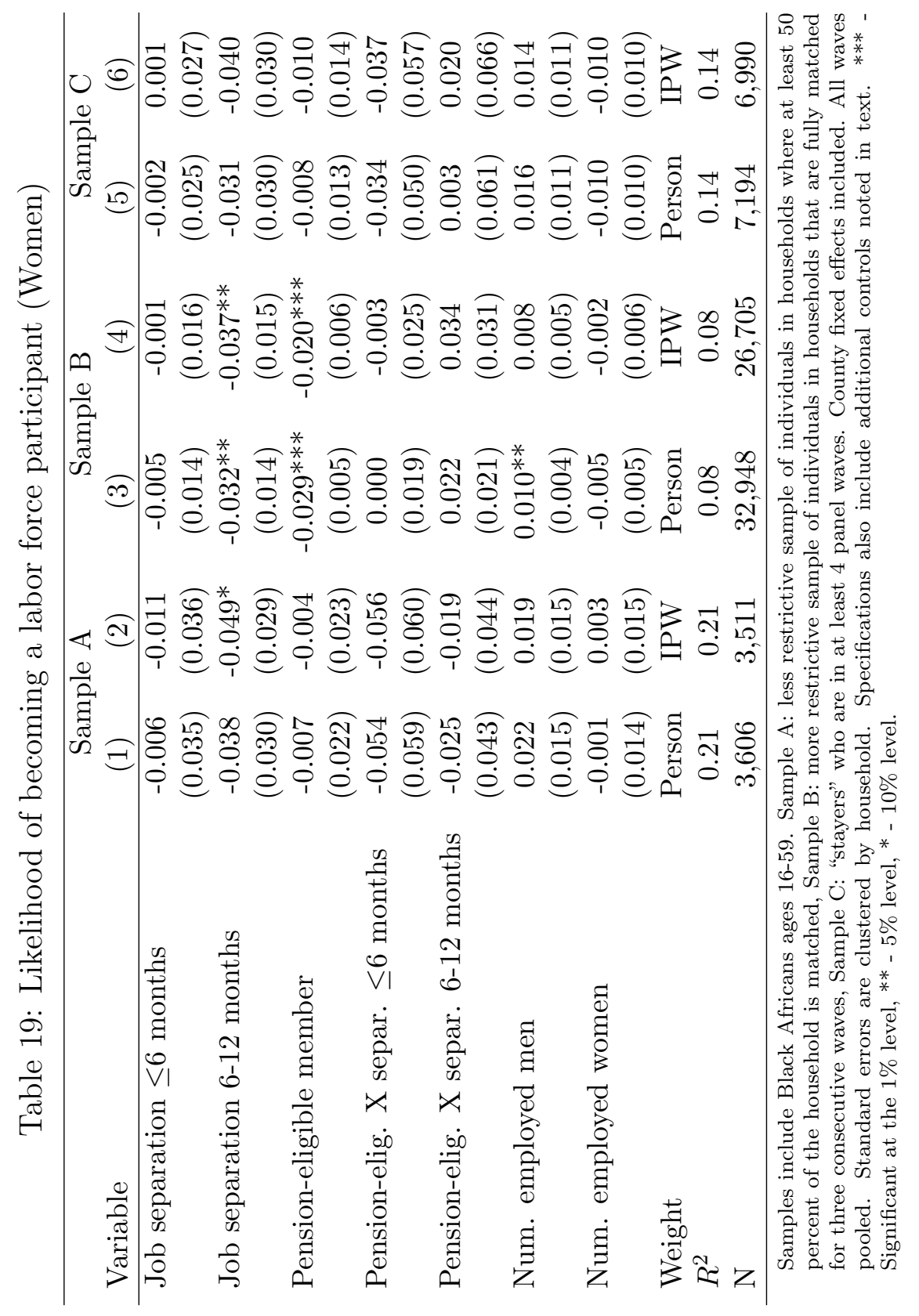




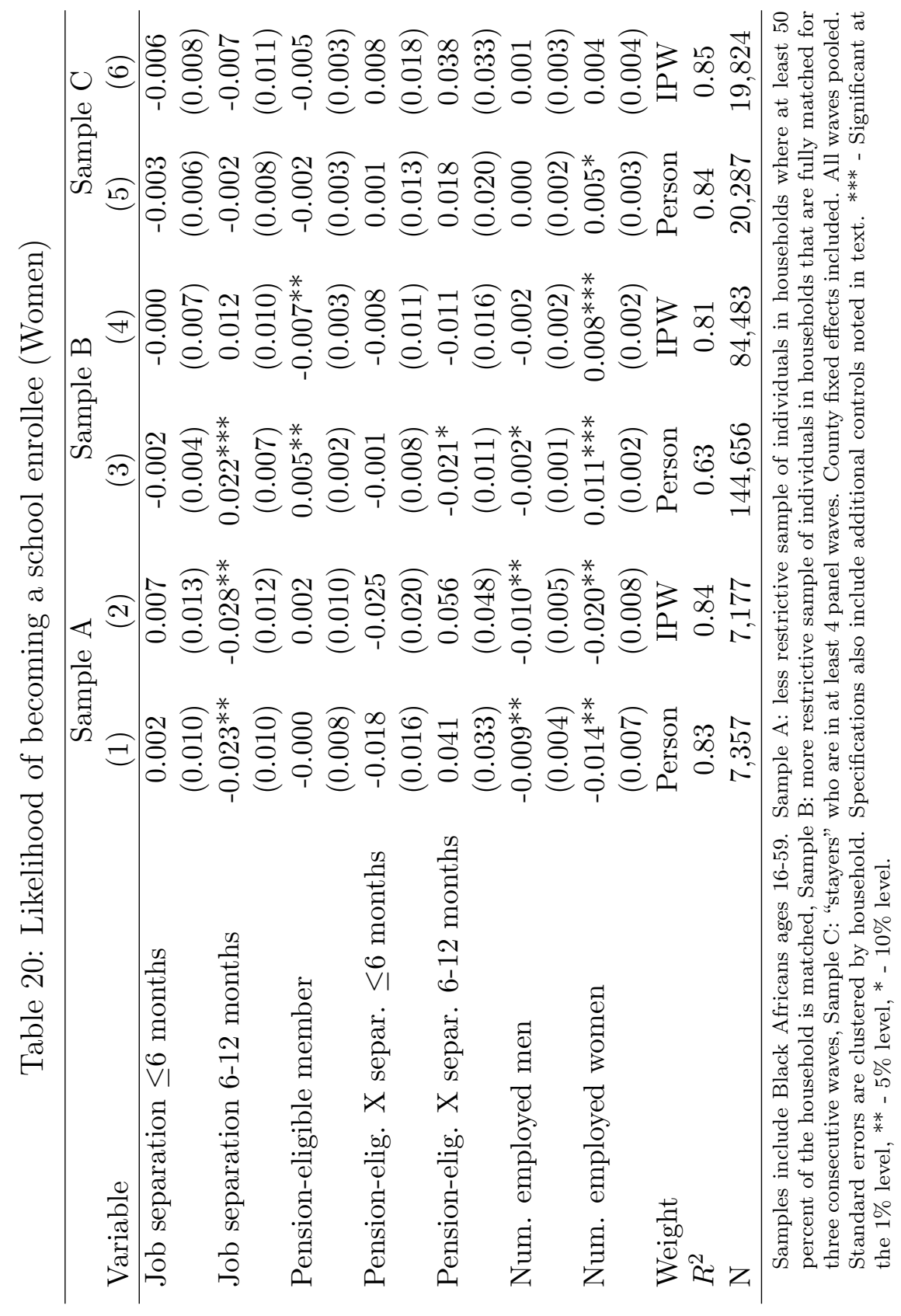




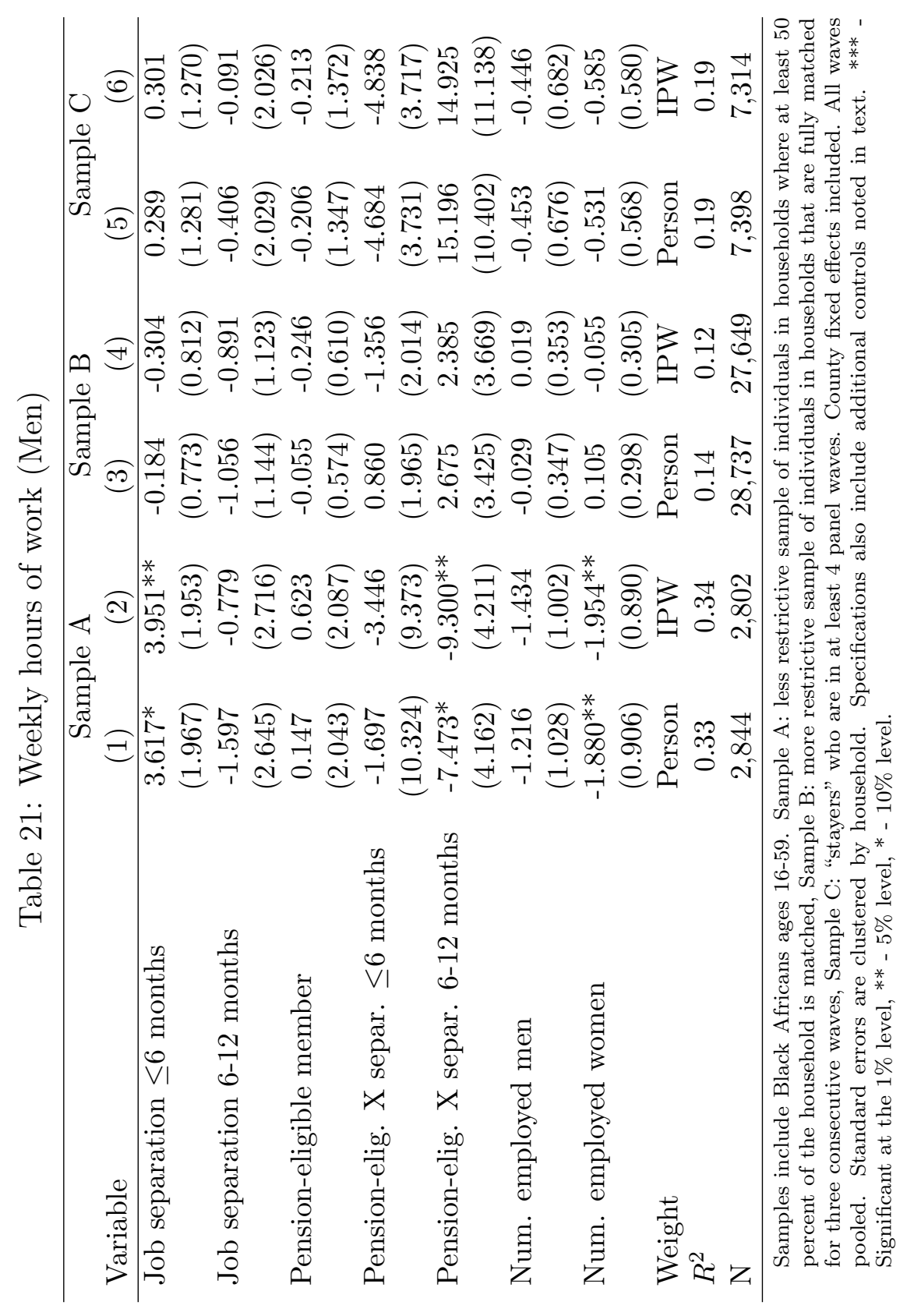




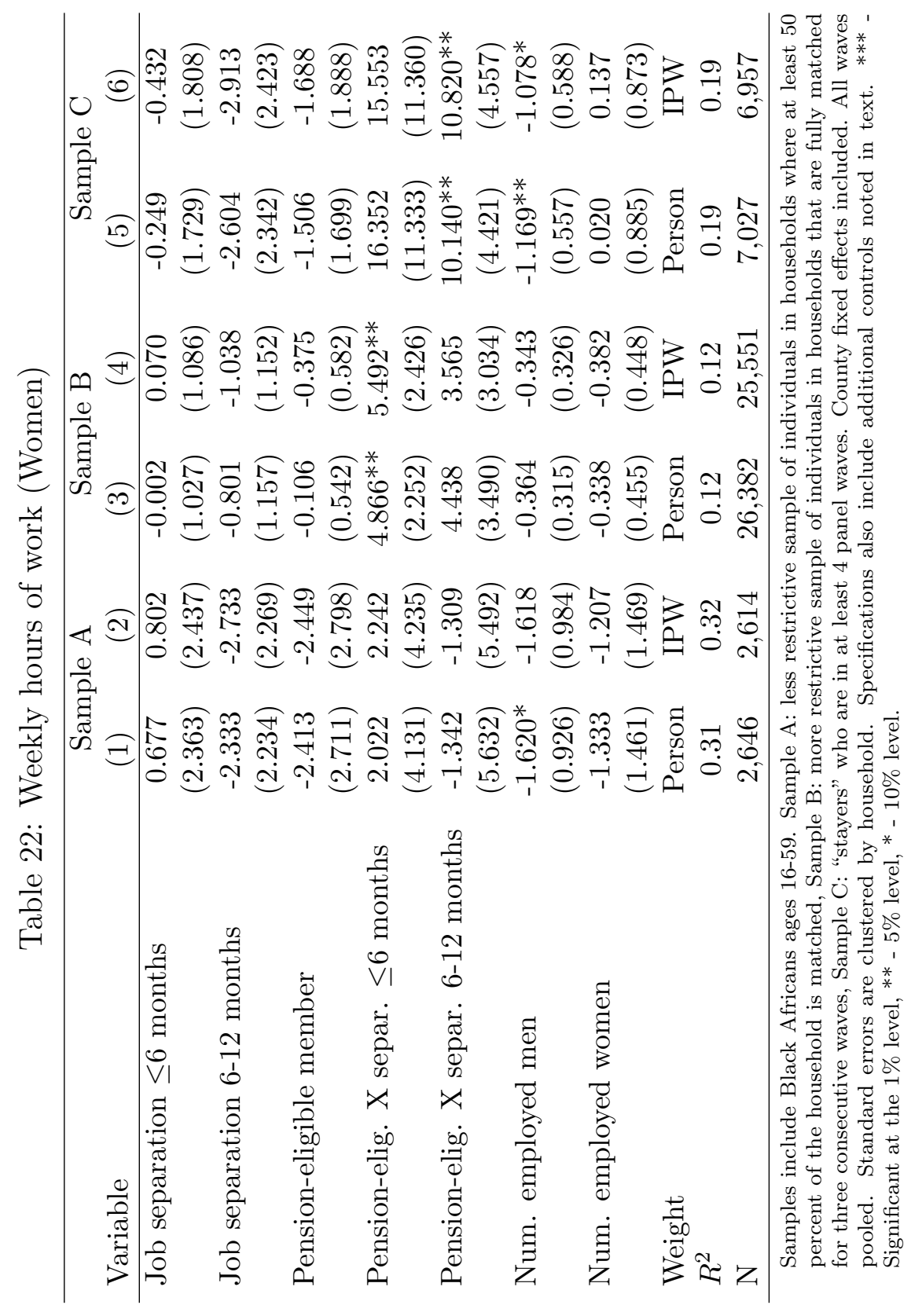




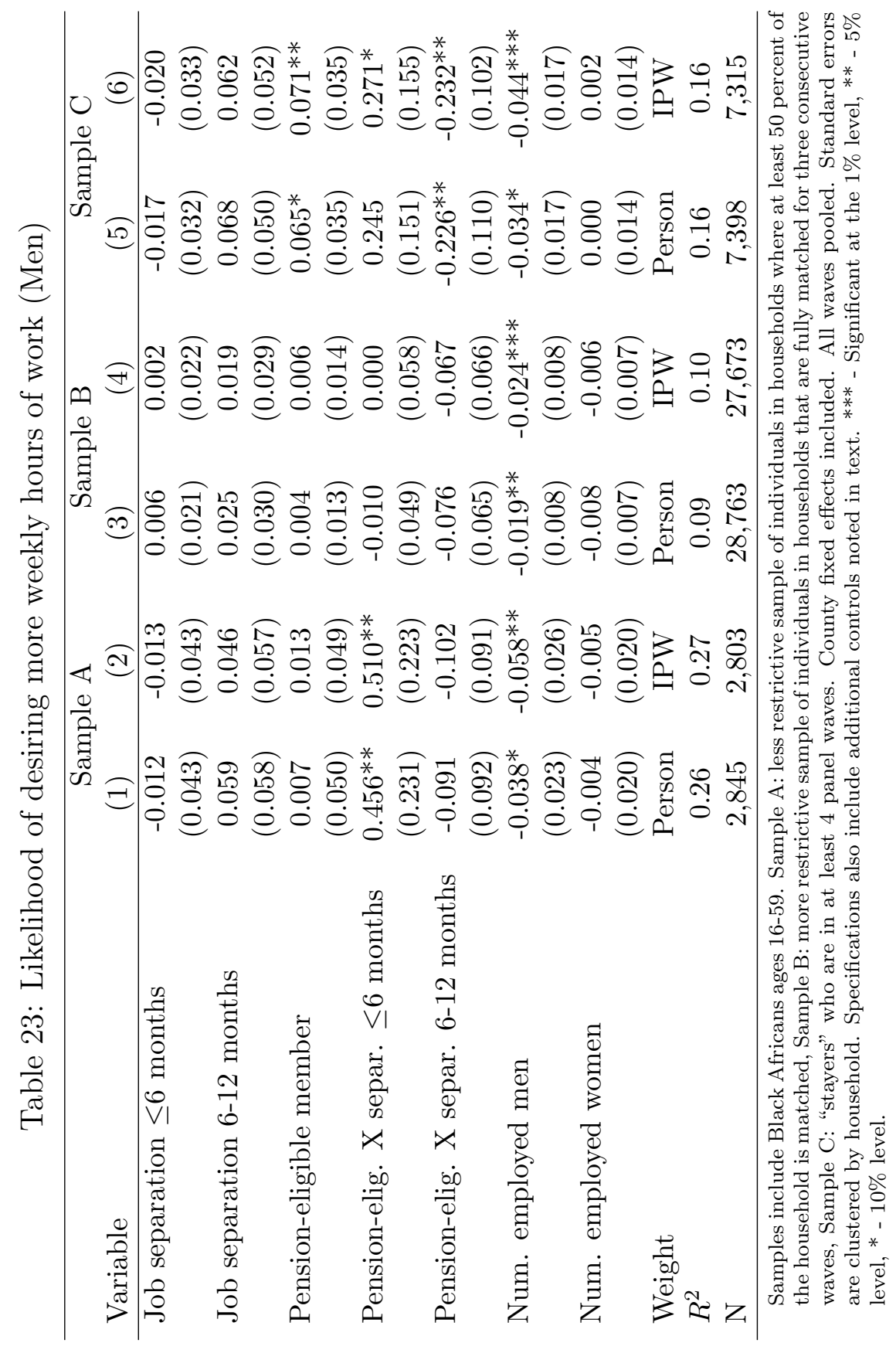




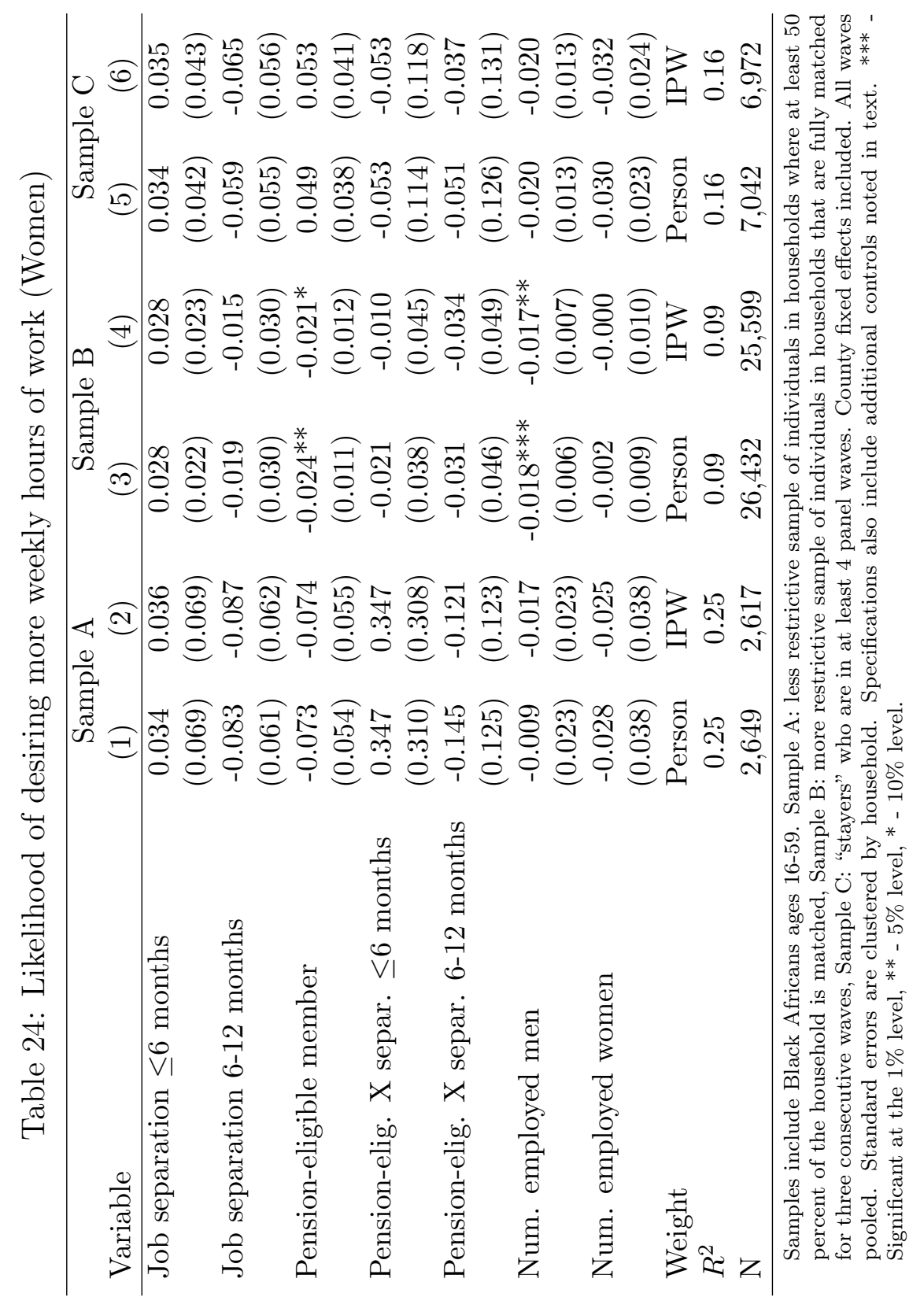




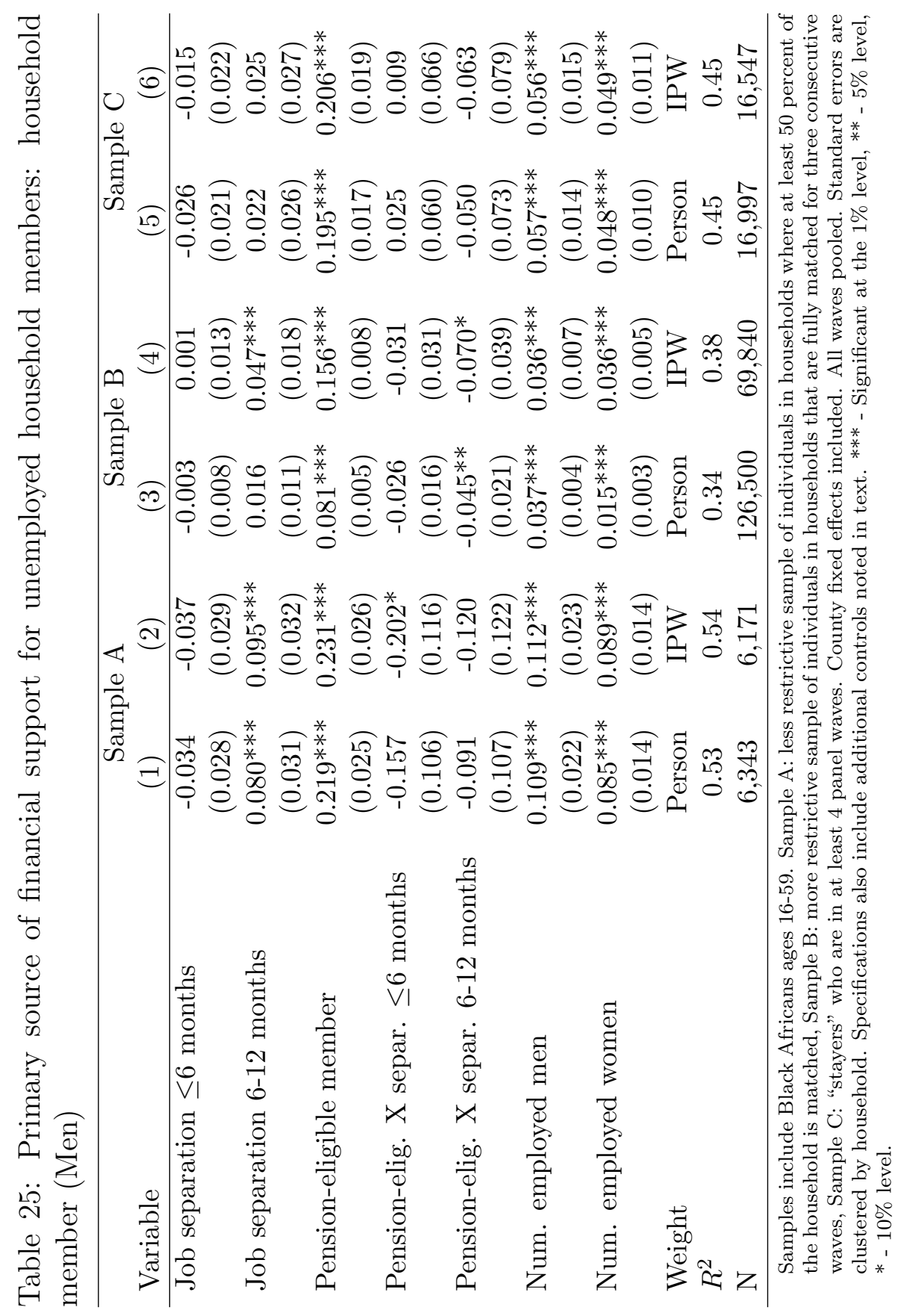




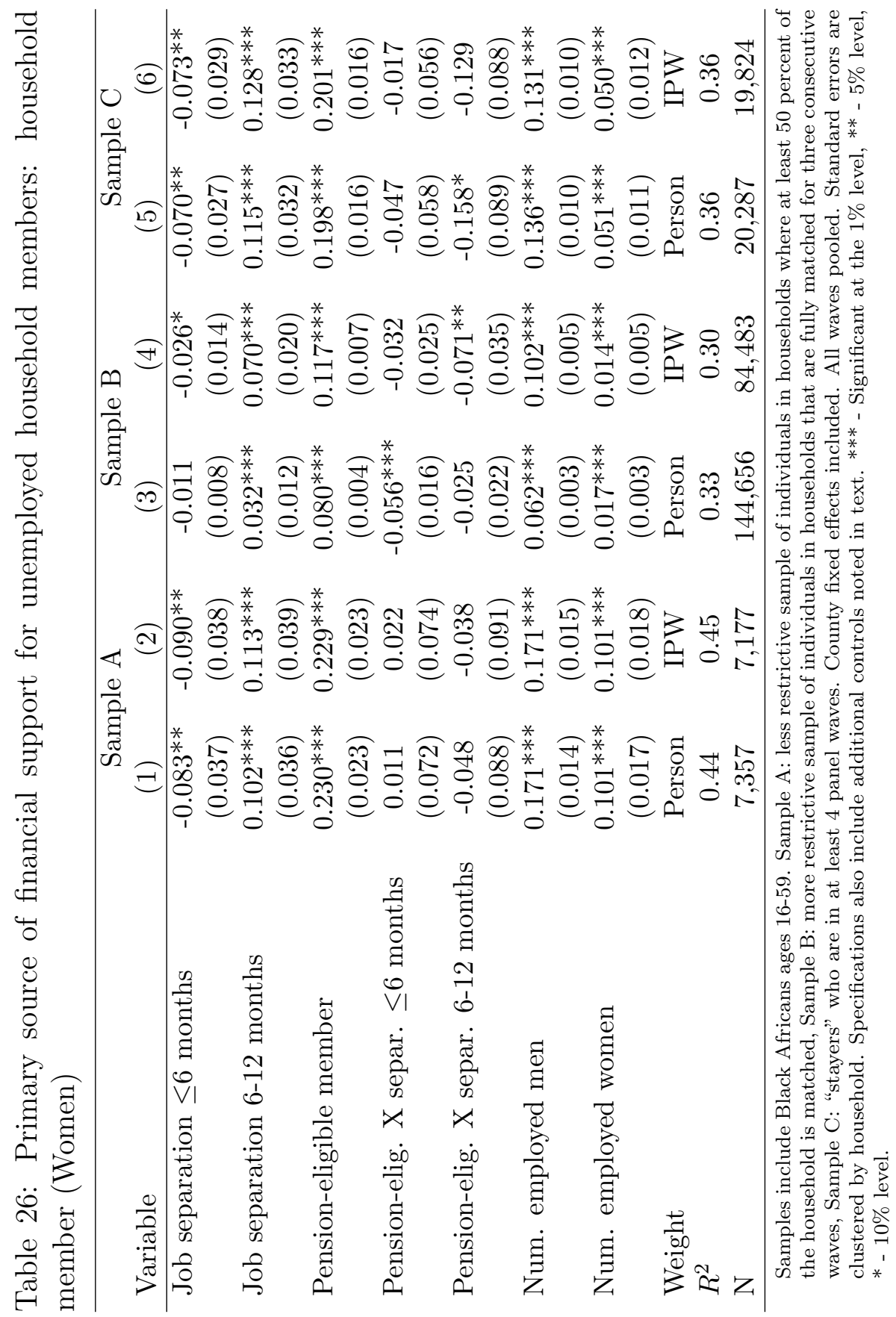




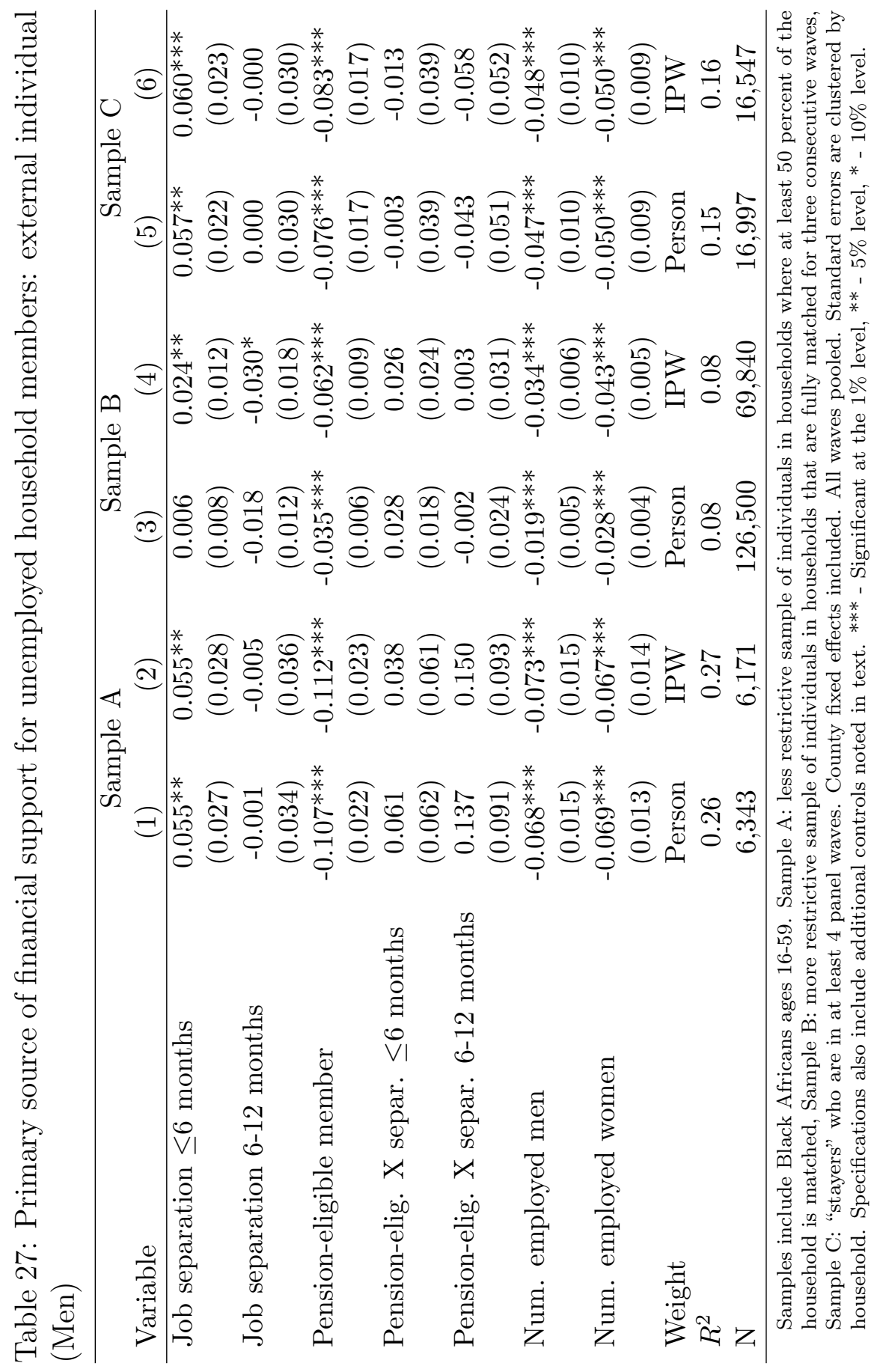




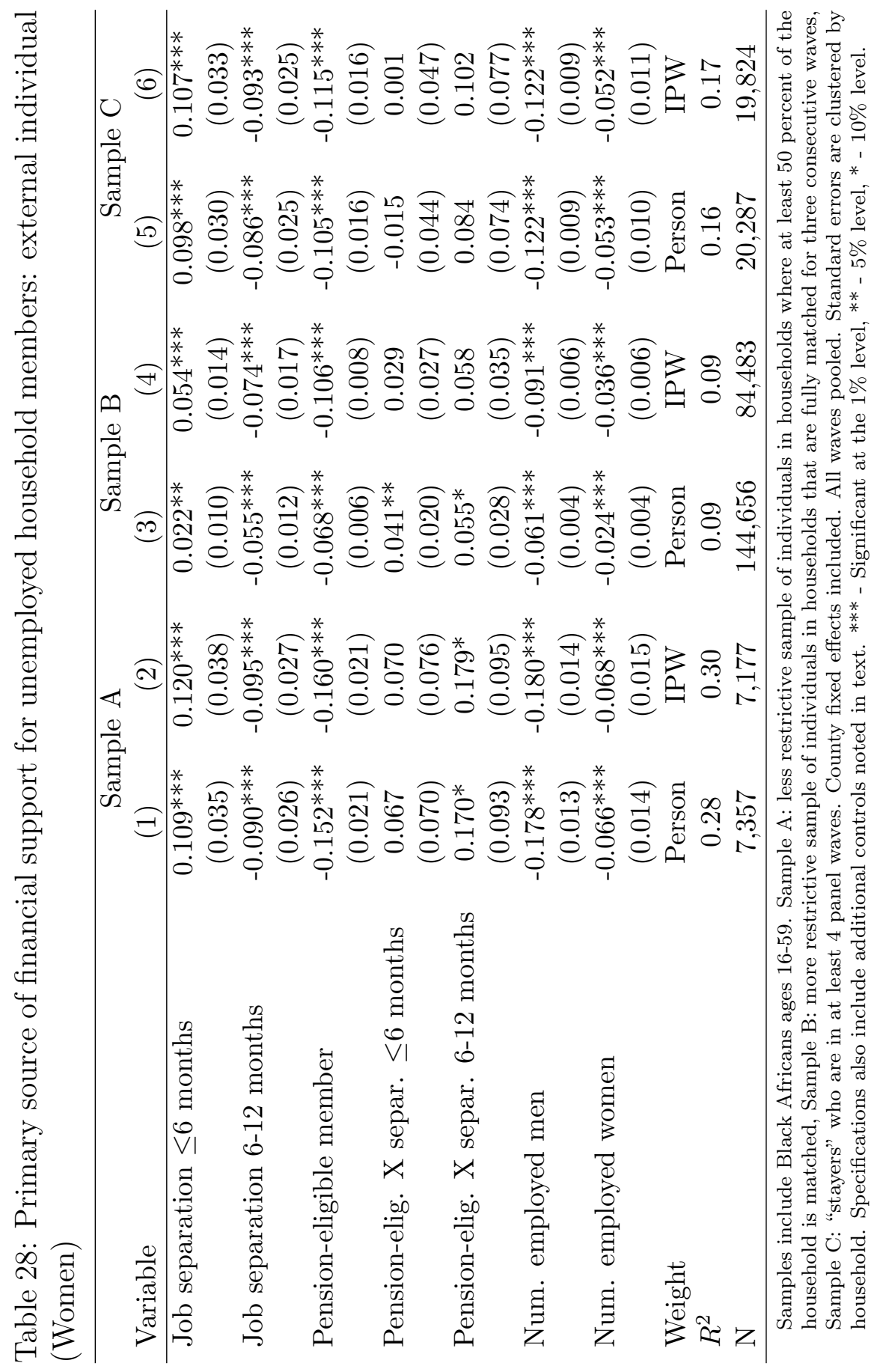




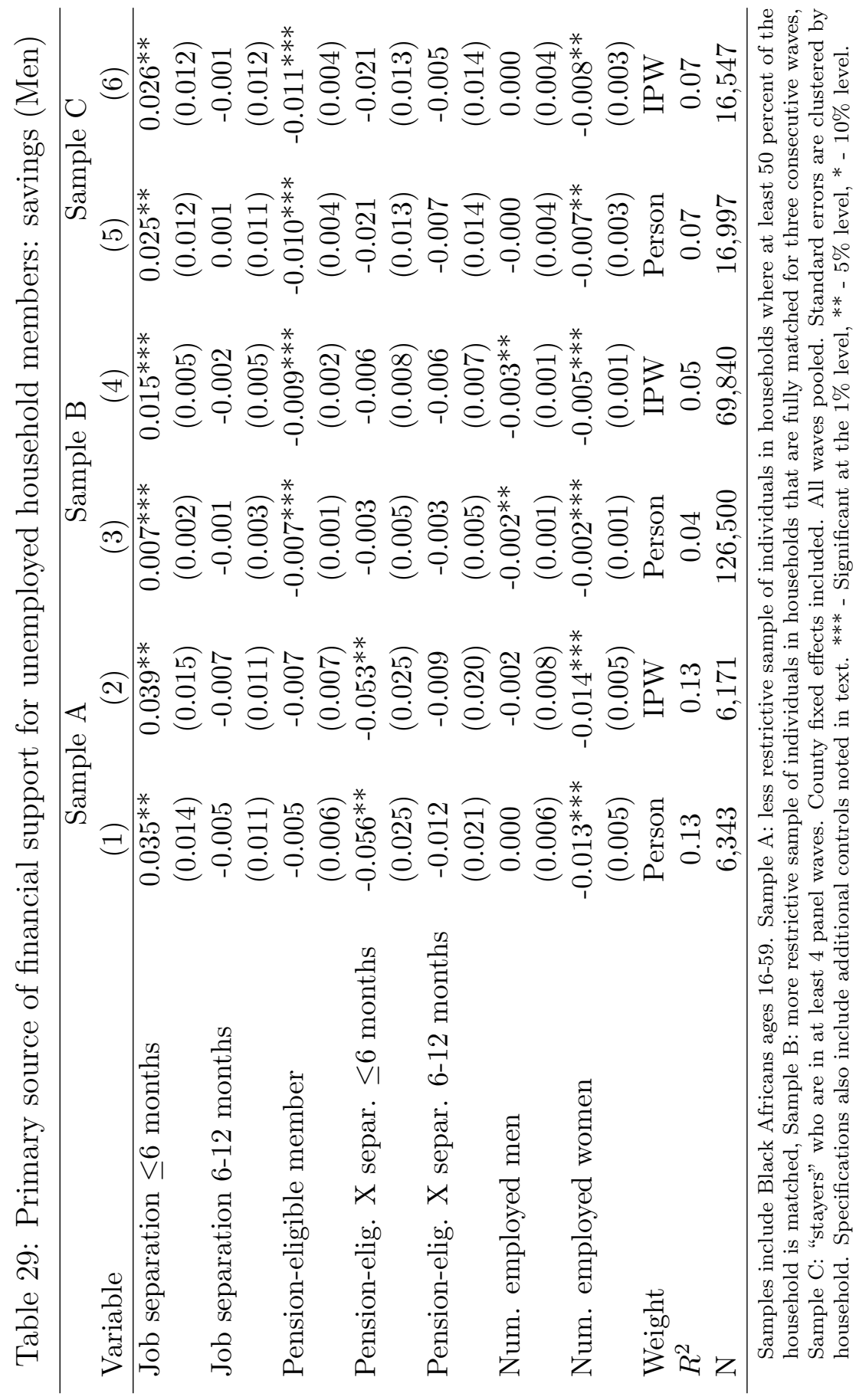




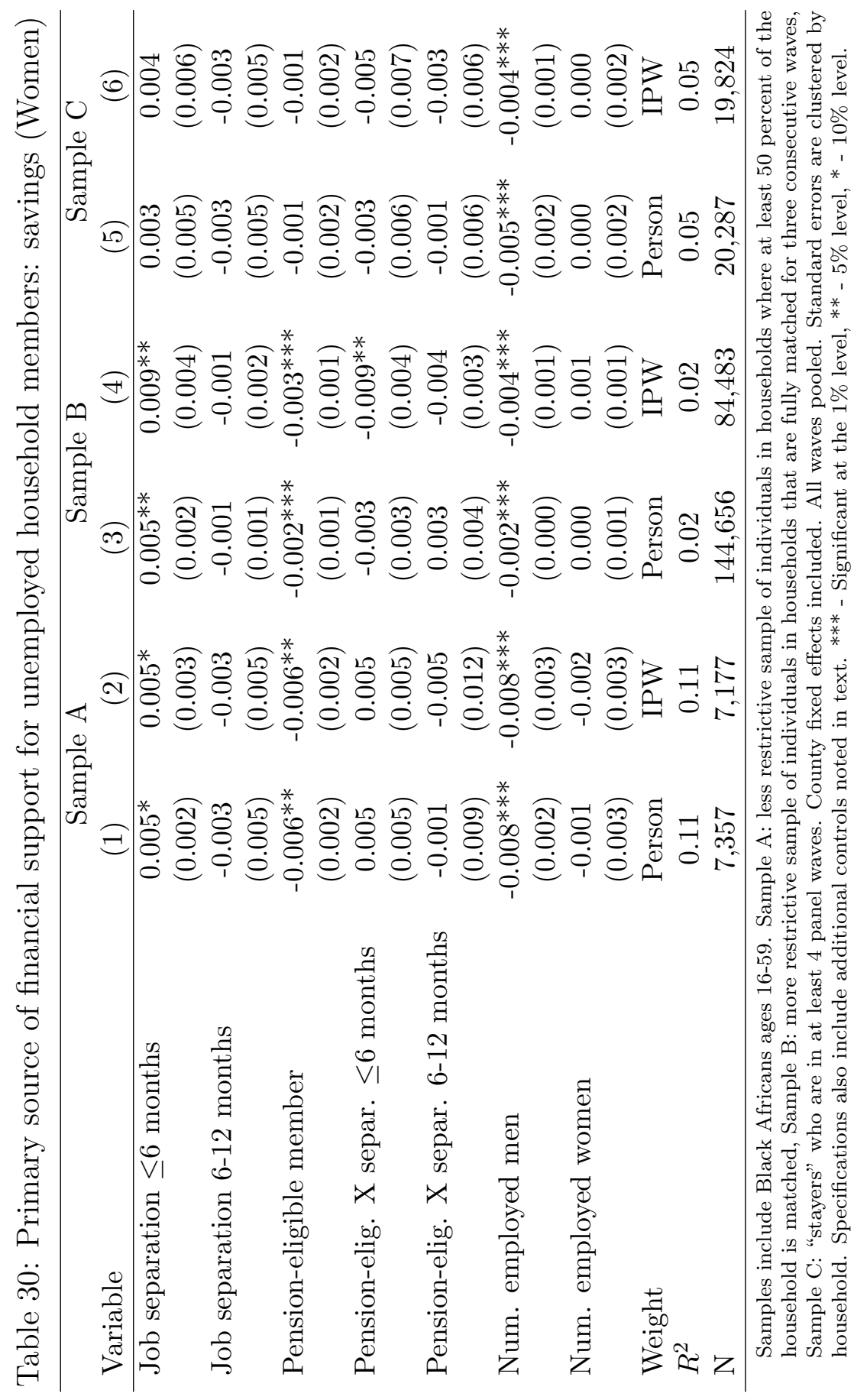




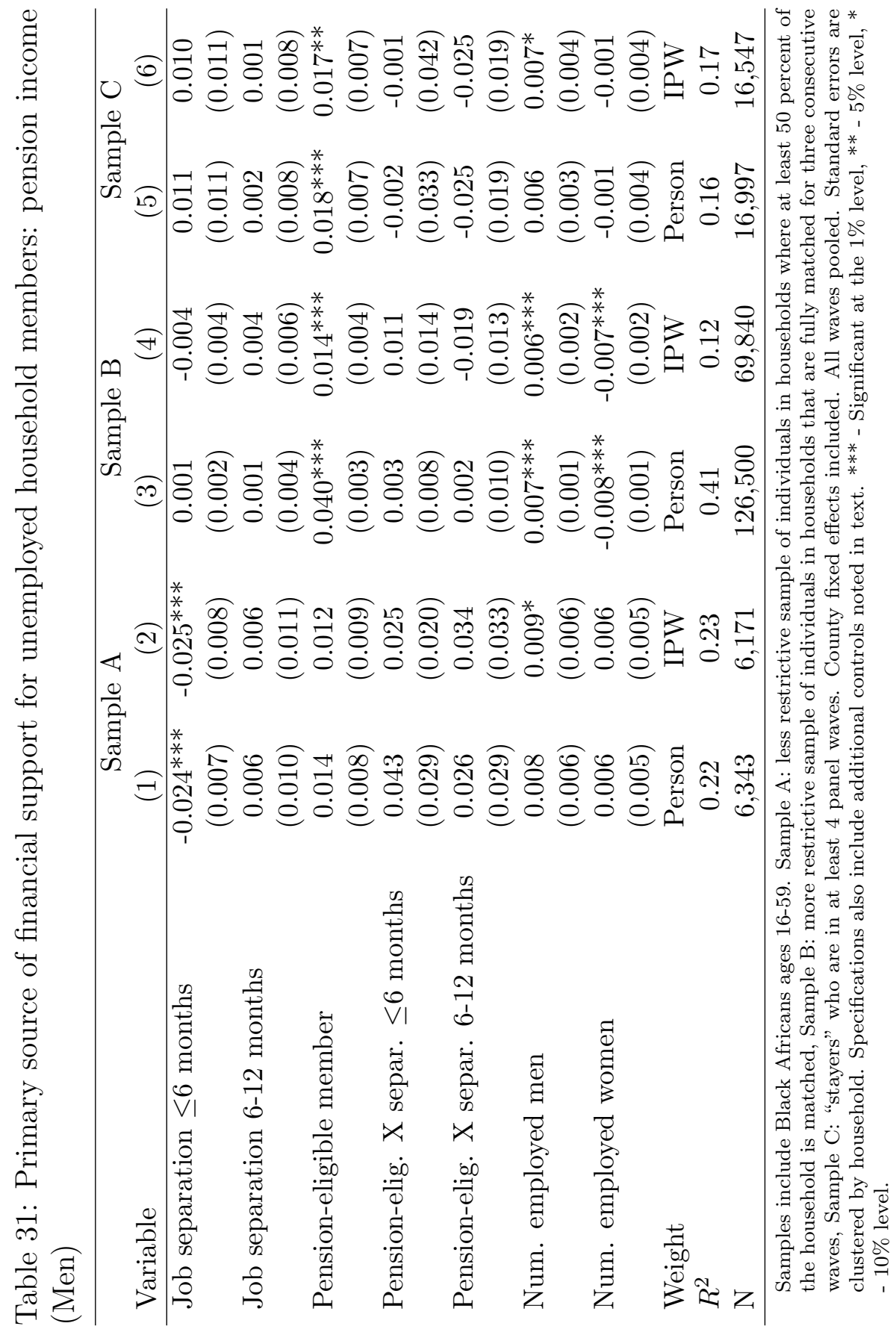




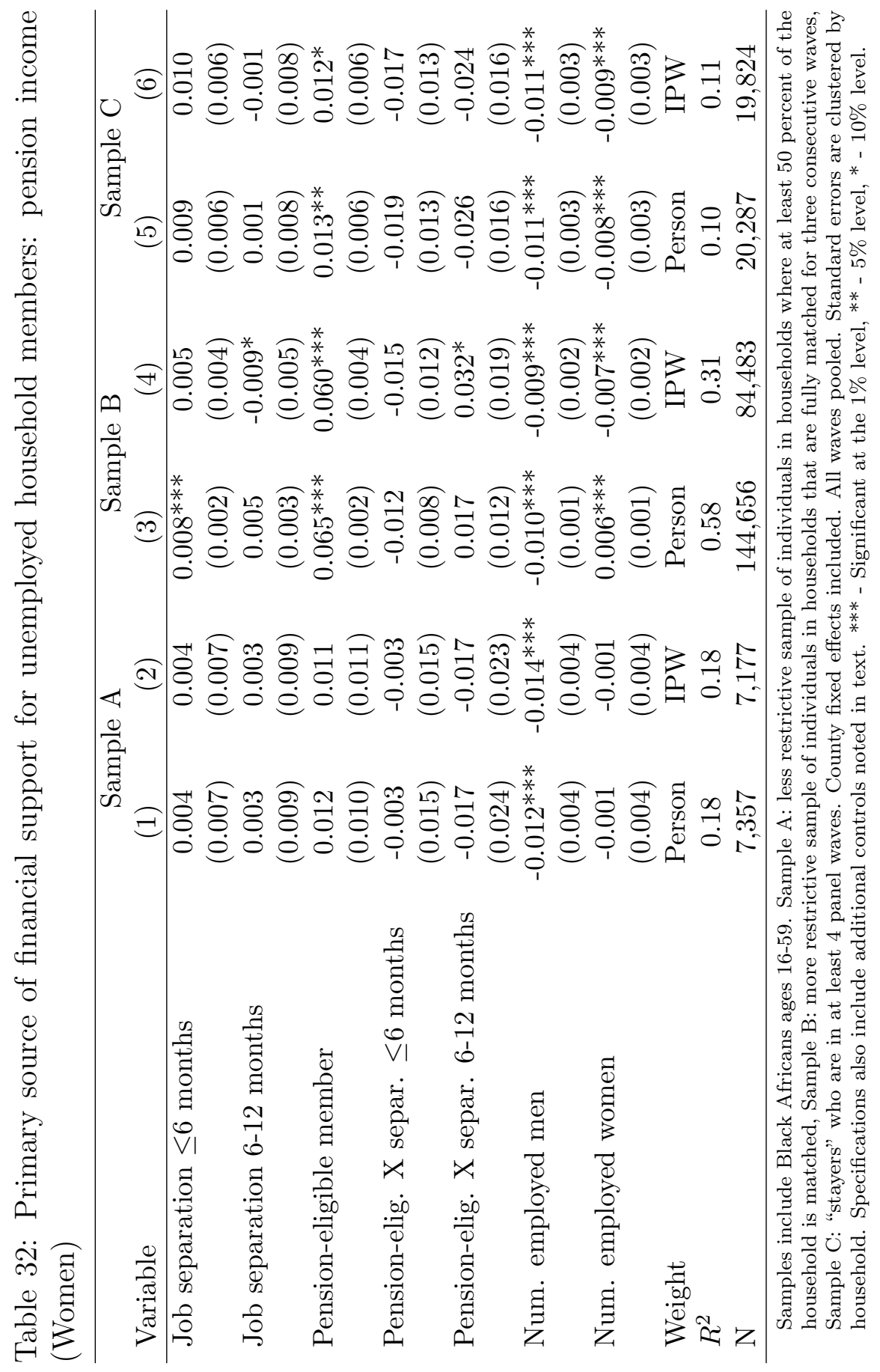




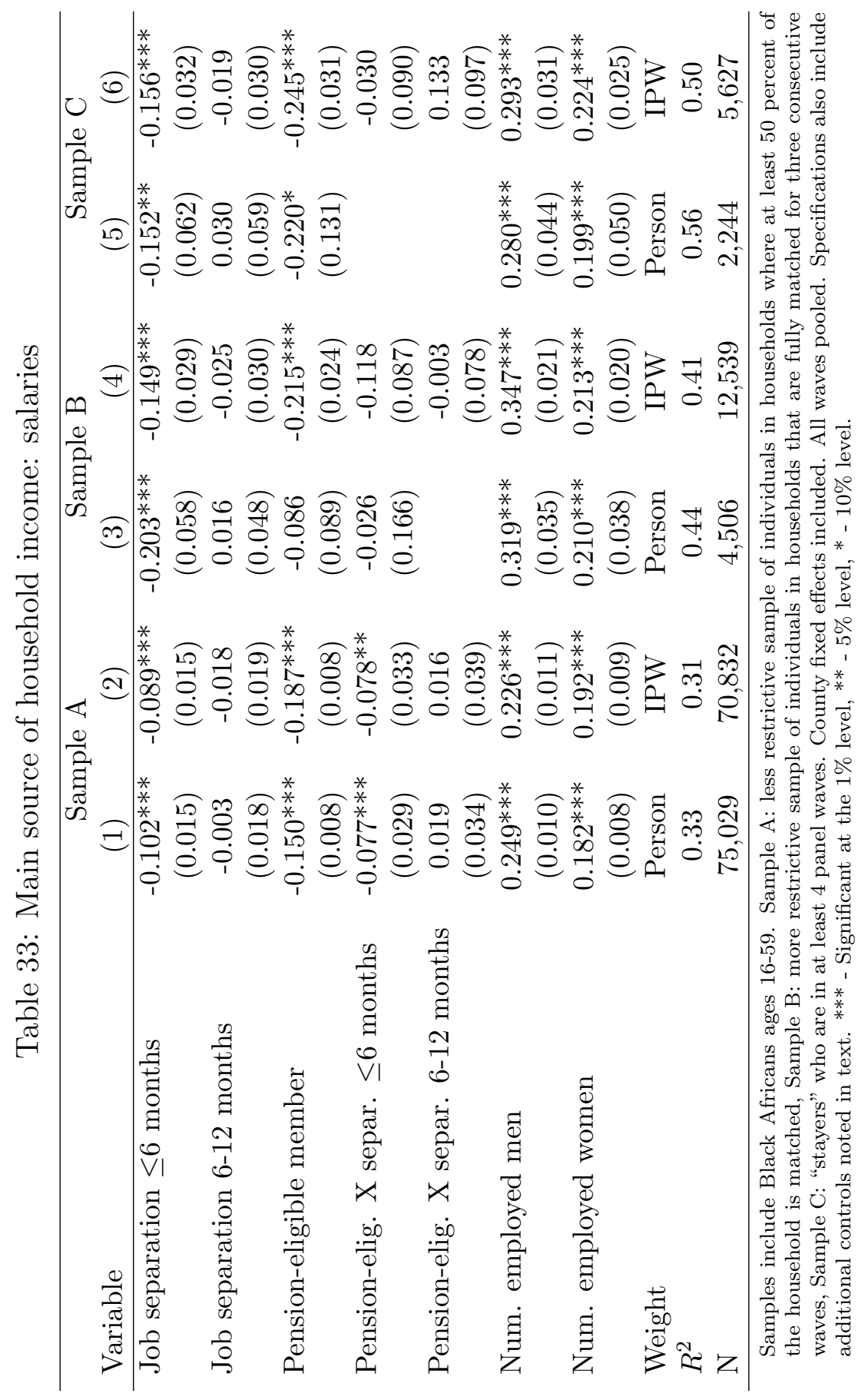




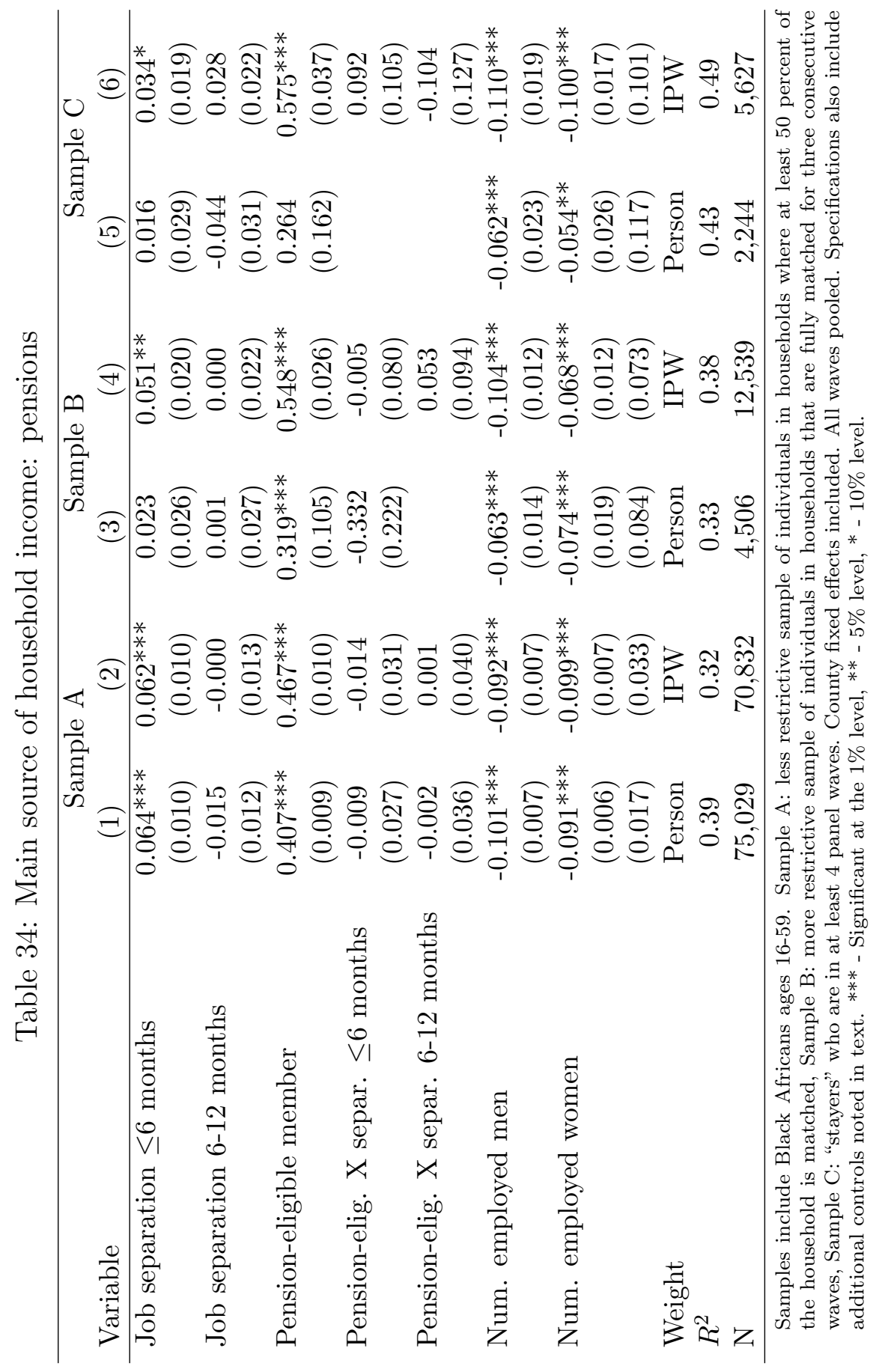




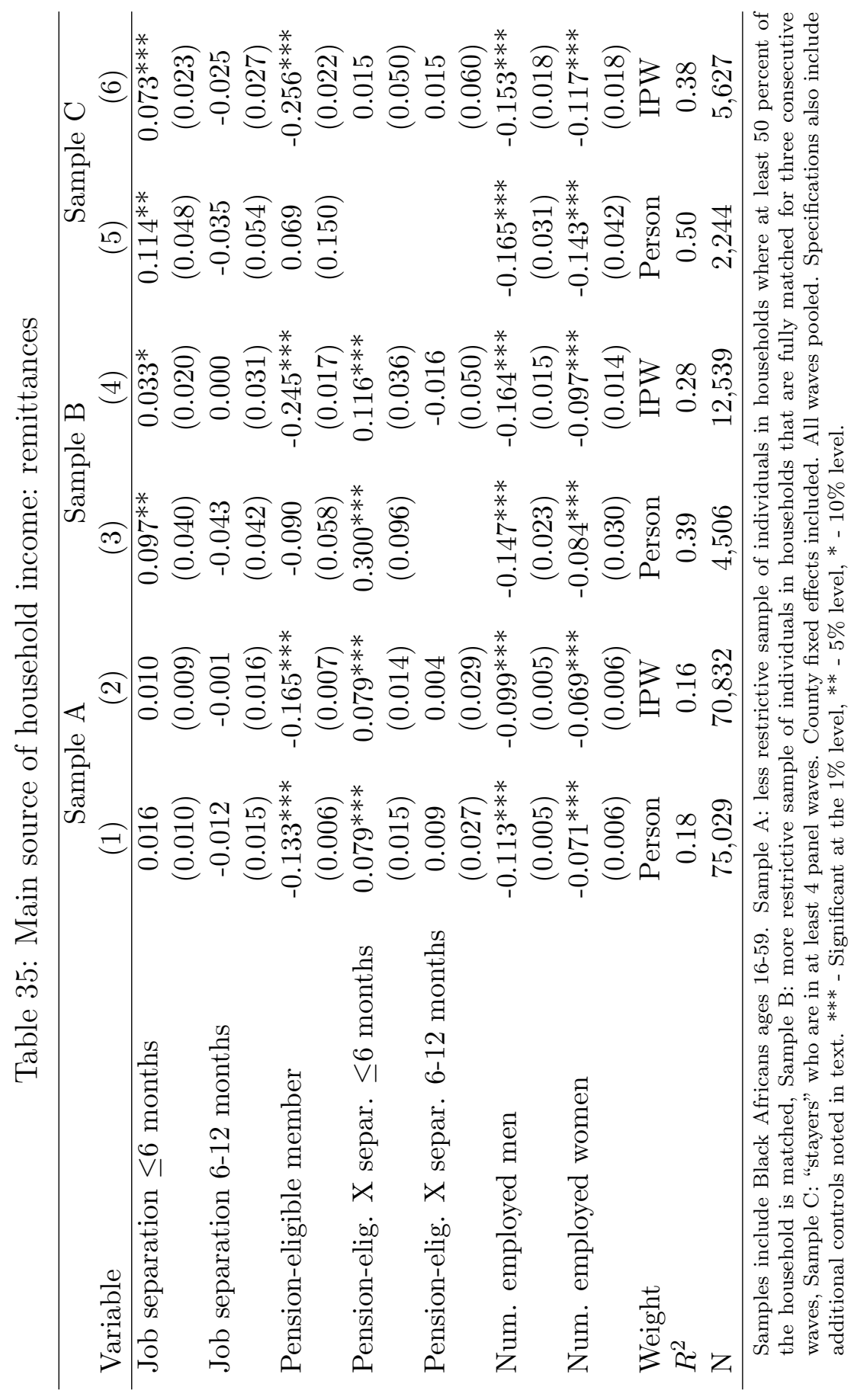




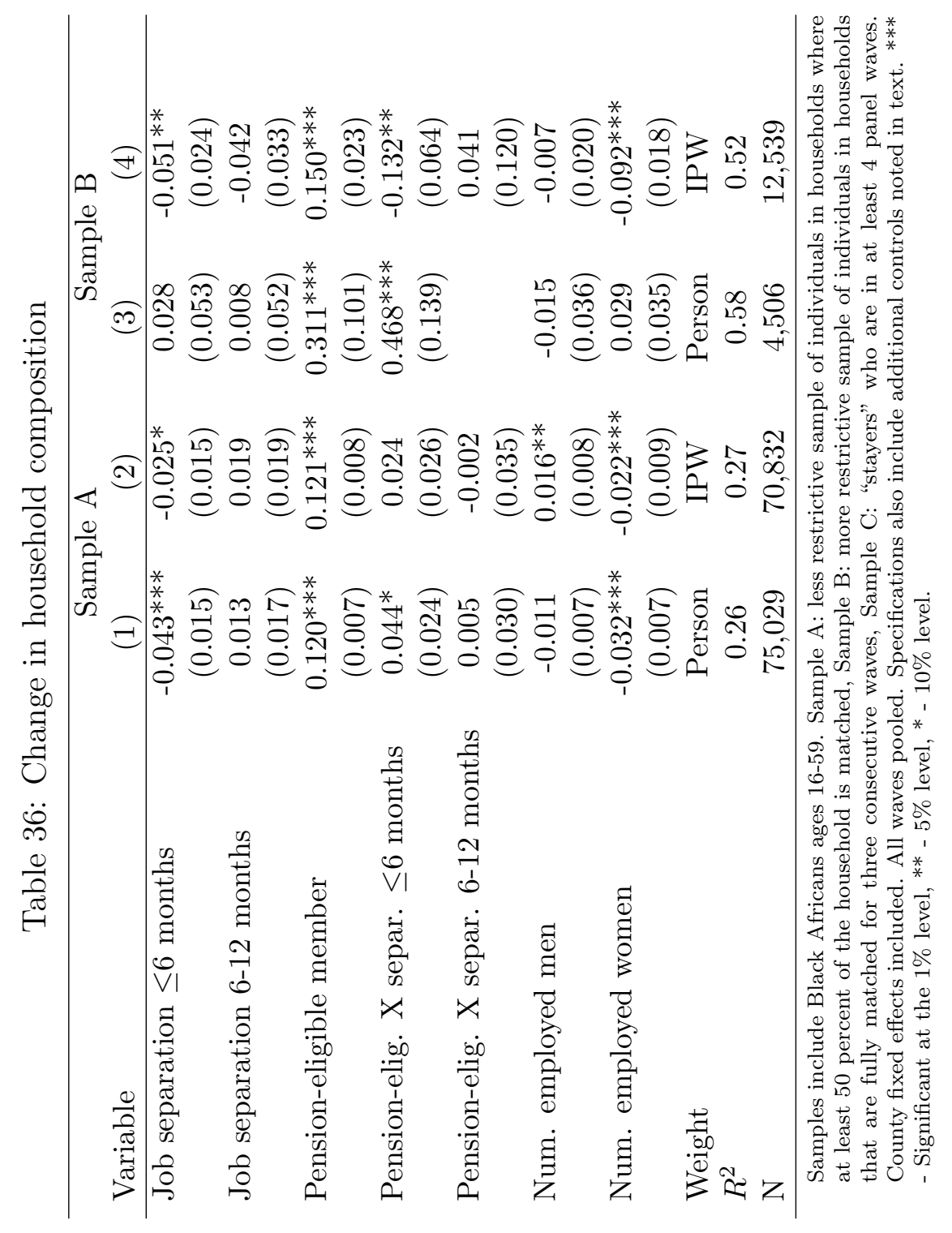




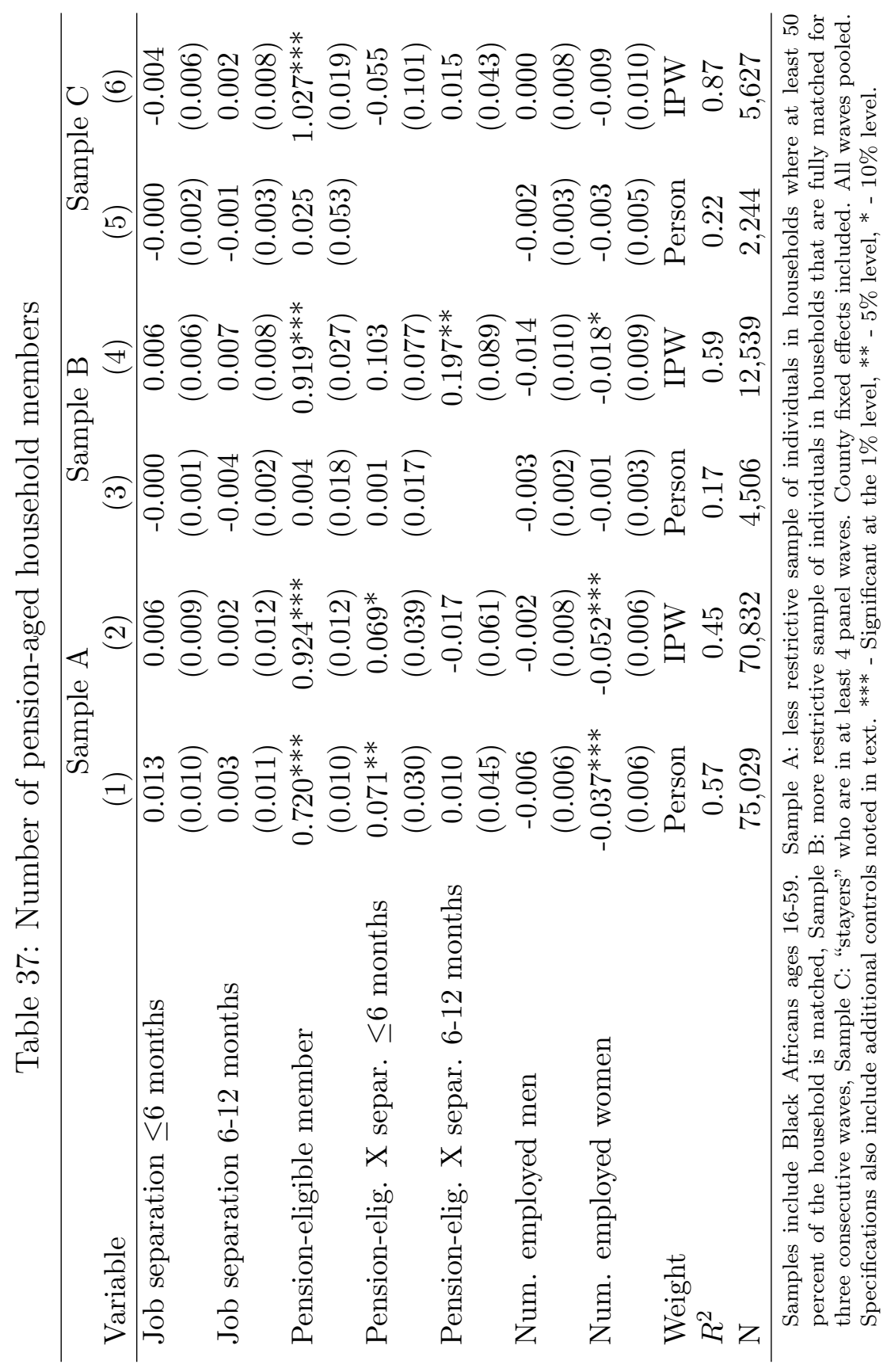




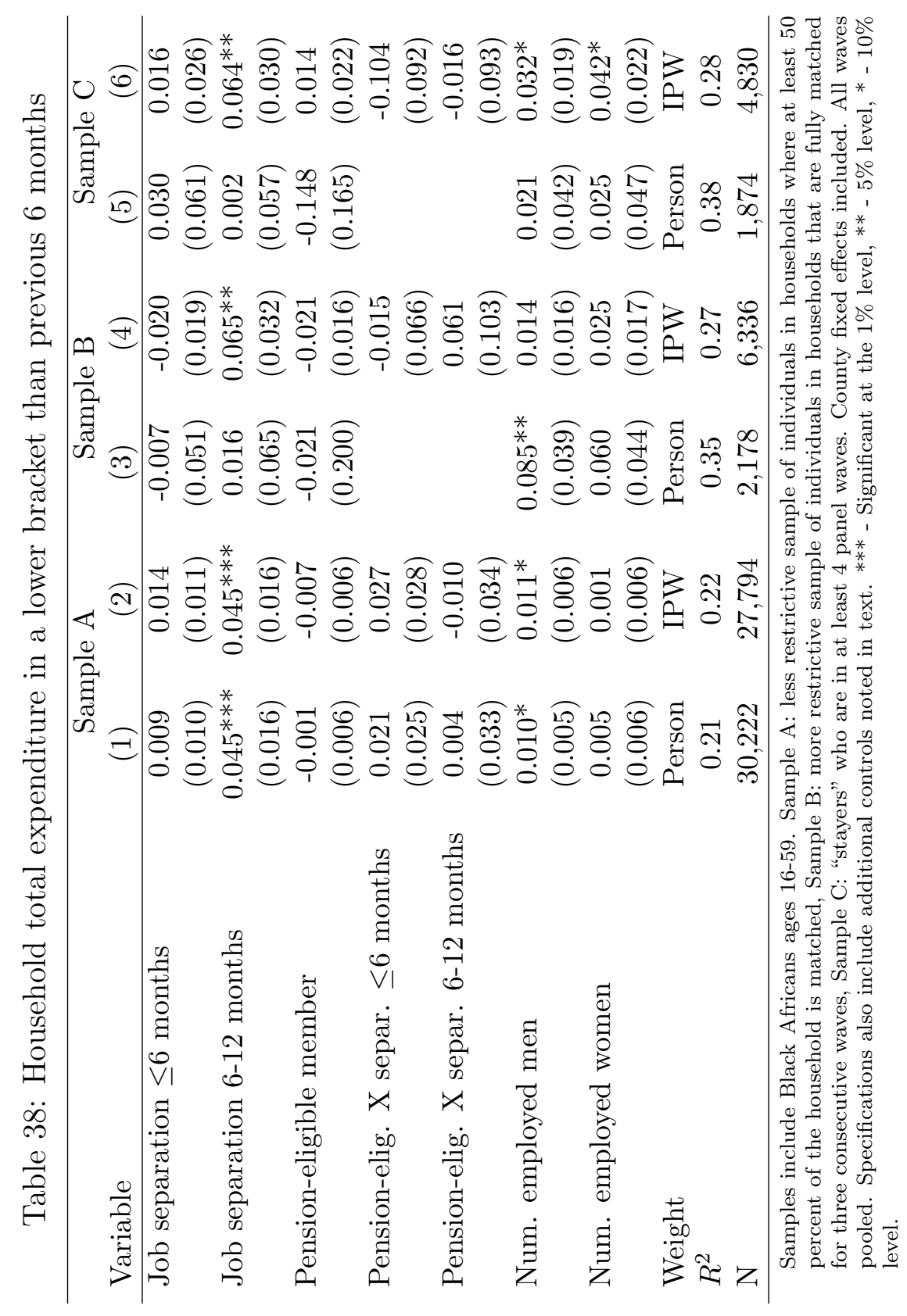




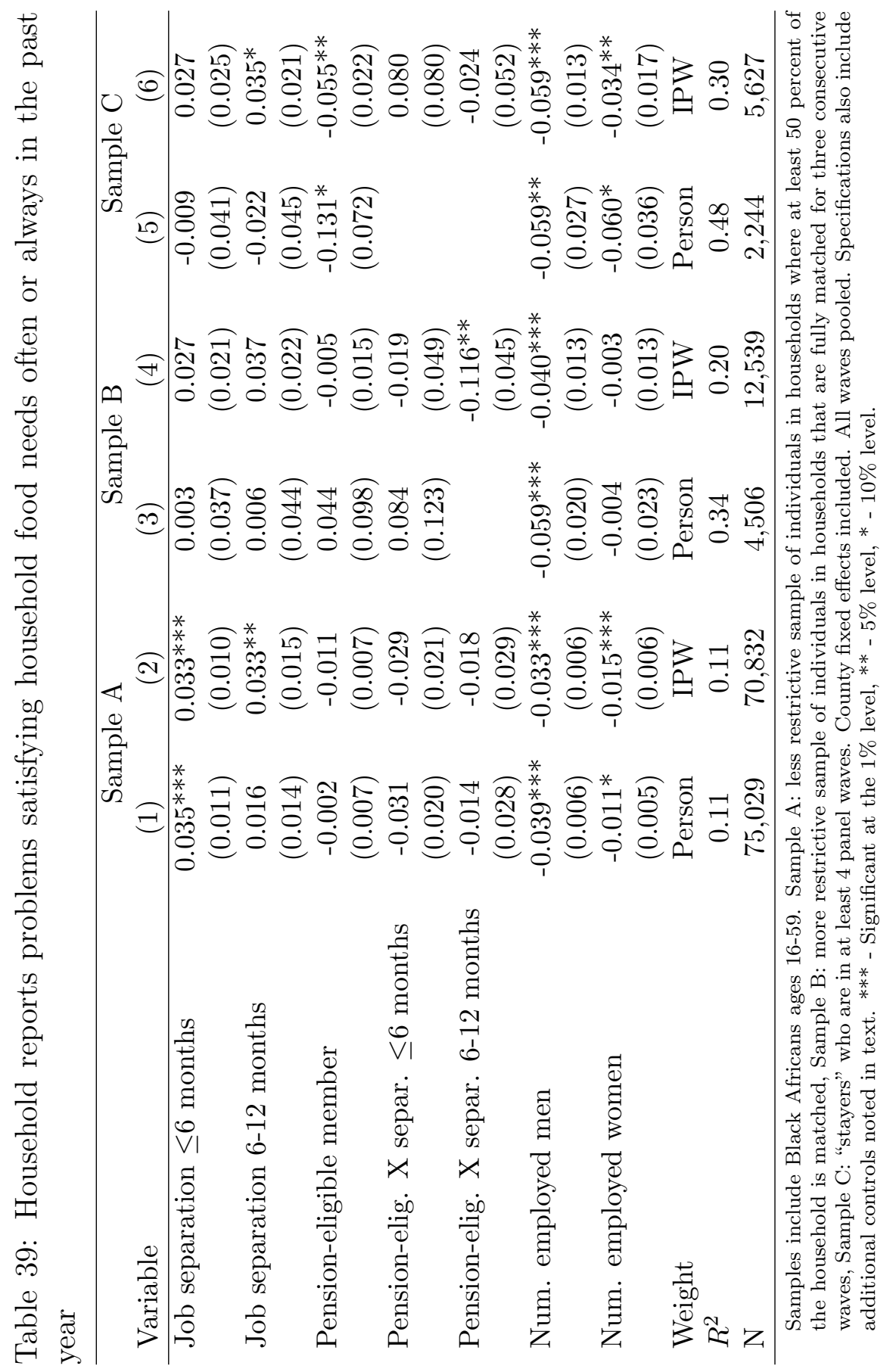




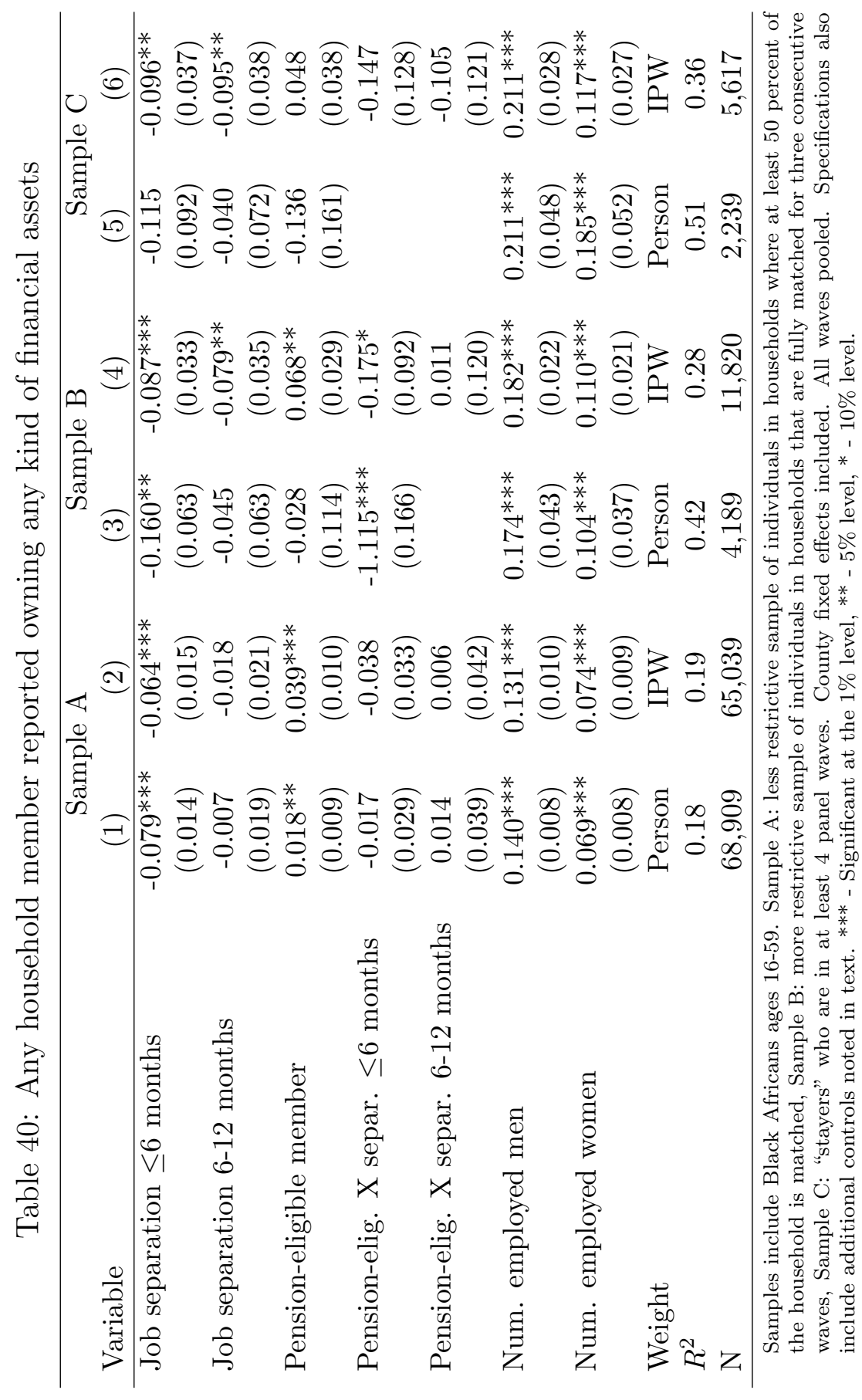




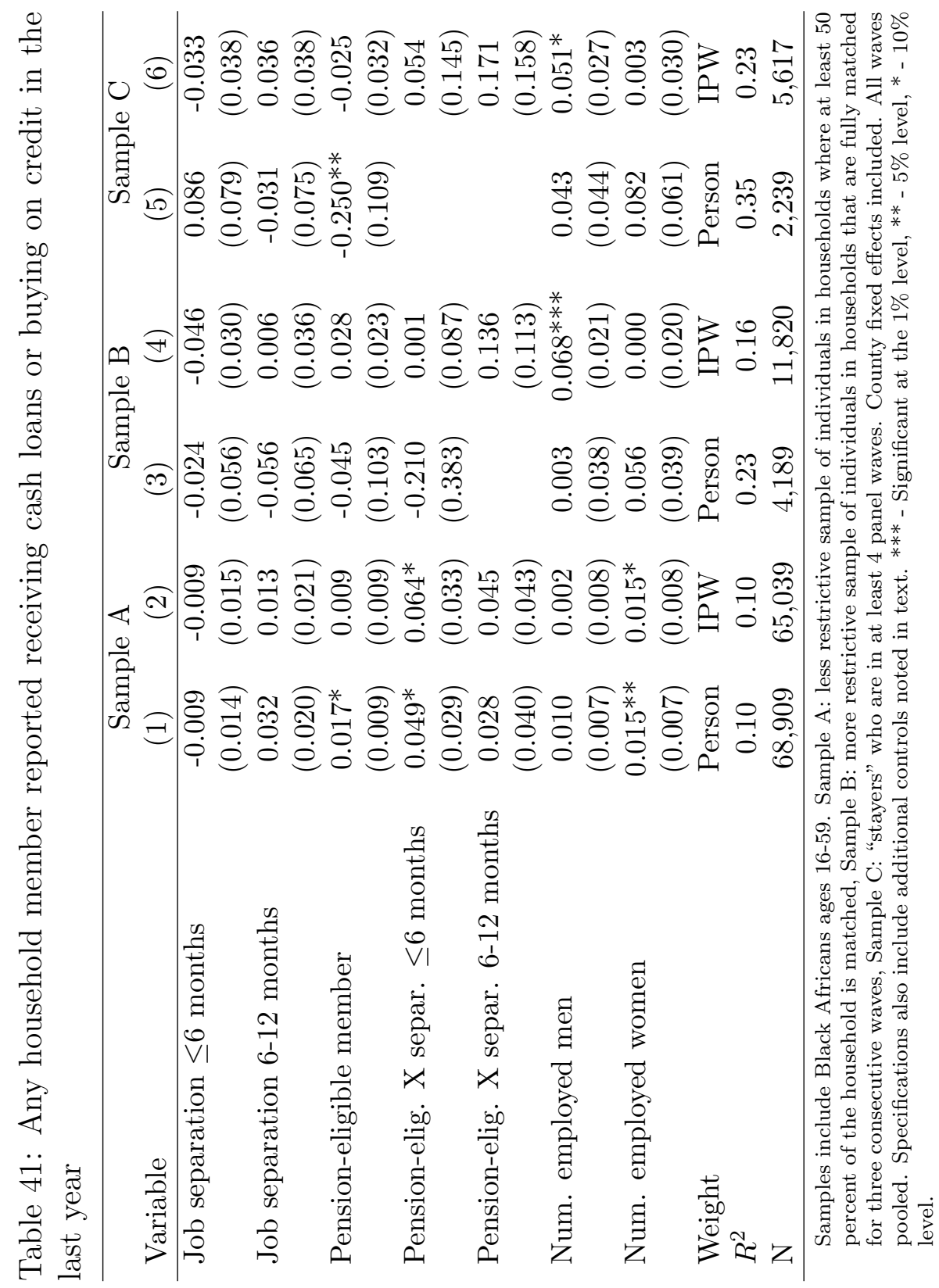

